\title{
Consumer Bankruptcy and Financial Health
}

\section{Citation}

Will Dobbie, Paul Goldsmith-Pinkham \& Crystal S. Yang, Consumer Bankruptcy and Financial Health (Harvard John M. Olin Discussion Paper Series Paper No. 821, Apr. 2015).

\section{Published Version}

http://www.law.harvard.edu/programs/olin_center/papers/pdf/Yang_821.pdf

\section{Permanent link}

http://nrs.harvard.edu/urn-3:HUL.InstRepos:17747469

\section{Terms of Use}

This article was downloaded from Harvard University's DASH repository, and is made available under the terms and conditions applicable to Other Posted Material, as set forth at http:// nrs.harvard.edu/urn-3:HUL.InstRepos:dash.current.terms-of-use\#LAA

\section{Share Your Story}

The Harvard community has made this article openly available.

Please share how this access benefits you. Submit a story.

\section{Accessibility}




\title{
HARVARD
}

JOHN M. OLIN CENTER FOR LAW, ECONOMICS, AND BUSINESS

\author{
CONSUMER BANKRUPTCY AND FINANCIAL HEALTH \\ Will Dobbie \\ Paul Goldsmith-Pinkham \\ Crystal S. Yang
}

Discussion Paper No. 821

$04 / 2015$

Harvard Law School

Cambridge, MA 02138

This paper can be downloaded without charge from:

The Harvard John M. Olin Discussion Paper Series:

http://www.law.harvard.edu/programs/olin_center/

The Social Science Research Network Electronic Paper Collection:

http://ssrn.com/abstract=2583581 


\title{
Consumer Bankruptcy and Financial Health*
}

\author{
Will Dobbie \\ Princeton University and NBER \\ Crystal Yang \\ Harvard Law School
}

Paul Goldsmith-Pinkham

Harvard University

March 2015

\begin{abstract}
This paper estimates the effect of Chapter 13 bankruptcy protection on post-filing financial outcomes using a new dataset linking bankruptcy filings to credit bureau records. Our empirical strategy uses the leniency of randomly-assigned judges as an instrument for Chapter 13 protection. Over the first five post-filing years, we find that Chapter 13 protection decreases an index measuring adverse financial events such as civil judgments and repossessions by 0.316 standard deviations, increases the probability of being a homeowner by 13.2 percentage points, and increases credit scores by 14.9 points. Chapter 13 protection has little impact on open unsecured debt, but decreases the amount of debt in collections by $\$ 1,315$.
\end{abstract}

${ }^{*}$ We thank Tal Gross, Matthew Notowidigdo, and Jialan Wang for providing the bankruptcy data used in this analysis. We also thank Lanier Benkard, Raj Chetty, Roland Fryer, Edward Glaeser, Guido Imbens, Lawrence Katz, Geng Li, and numerous seminar participants for helpful comments and suggestions. Jessica Wagner provided outstanding research assistance. Correspondence can be addressed to the authors by e-mail: wdobbie@princeton.edu [Dobbie], pgoldsm@fas.harvard.edu [Goldsmith-Pinkham], or cyang@law.harvard.edu [Yang]. All remaining errors are our own. 
America is a nation of debtors. The amount of debt held by the average American consumer increased from $\$ 31,840$ to $\$ 45,500$ between 2003 and 2013, with more than 14 percent of consumers having at least one debt in collections by 2013 (Federal Reserve Bank of New York 2014). Theoretical work has long suggested that excessive debt and financial distress can distort repayment, consumption, and labor supply decisions (e.g. Myers 1977, Krugman 1988). For example, borrowers with excessive debt have an incentive to avoid repayment through strategies with significant deadweight costs, such as leaving the formal banking system to avoid seizure of assets or leaving the formal labor market to avoid wage garnishment. Consistent with this literature, recent empirical work shows that debt overhang reduces labor supply (Dobbie and Song forthcoming) and increases mortgage default rates (Melzer 2012). ${ }^{1}$ Perhaps the most important program meant to alleviate the adverse consequences of financial distress is the consumer bankruptcy system, the legal process to resolve unpaid debts in the United States.

The consumer bankruptcy system allows debtors to choose between Chapter 7 bankruptcy, which provides debt relief and protection from wage garnishment in exchange for a debtor's nonexempt assets, and Chapter 13 bankruptcy, which adds the protection of most assets in exchange for a partial repayment of debt. Each year, more than one million Americans file for bankruptcy protection, with nearly one in ten American households having filed for bankruptcy at some point in their lifetimes (Stavins 2000). In terms of financial distress, bankruptcy filers are nearly two and half times as likely to have a delinquent debt before filing compared to the typical credit user, twice as likely to have a debt in collections, and three times as likely to have a lien or repossession. Even after filing, bankruptcy filers are much more likely to experience financial distress than otherwise similar individuals. ${ }^{2}$

Despite over one percent of American households filing for bankruptcy each year, little is known about whether bankruptcy protection reduces or exacerbates financial distress. In theory, bankruptcy protection benefits debtors directly by improving their balance sheets and preventing the seizure of important assets such as a home or car. These direct benefits may in turn indirectly benefit debtors by increasing their credit score or access to credit. Yet, in practice, there is little empirical evidence that bankruptcy protection provides any economically significant benefits to debtors. Cross-sectional comparisons suggest that bankruptcy filers work about the same number of hours and accumulate less wealth than non-filers (Han and Li 2007, 2011), and within-individual comparisons show that filers have less access to credit after receiving bankruptcy protection (CohenCole, Duygan-Bump and Montoriol-Garriga 2013, Jagtiani and Li 2014). However, much of this

\footnotetext{
${ }^{1}$ There is also evidence that financial distress imposes negative externalities on nearby individuals. For example, home foreclosures can reduce nearby home values (e.g. Campbell, Giglio, and Pathak 2011, Mian, Sufi, and Trebbi 2011) and consumer debt overhang can depress regional consumption and employment (e.g. Guerrieri and Lorenzoni 2011, Hall 2011, Midrigan and Philippon 2011, Eggertsson and Krugman 2012, Farhi and Werning 2013, Mian, Rao, and Sufi 2013, Mian and Sufi forthcoming).

${ }^{2}$ See Table 1 for details and additional summary statistics.
} 
prior work has been hampered by the lack of a plausible comparison group. Bankruptcy filers likely had worse outcomes even before filing, biasing cross-sectional estimates, and the most commonly reported causes of filing, such as job loss, also impact later outcomes, biasing within-individual estimates. $^{3}$

This paper uses a new dataset linking bankruptcy filings to credit bureau records to estimate the impact of Chapter 13 bankruptcy protection on post-filing financial outcomes. We estimate the expost causal effect of Chapter 13 protection by comparing the outcomes of filers randomly assigned to bankruptcy judges with different propensities to grant bankruptcy protection. The identified parameter measures the treatment effect for filers whose bankruptcy decision is altered by the judge assignment due to disagreement on whether or not they should receive bankruptcy protection (i.e. the marginal recipients of bankruptcy protection). The estimates hold fixed any independent effects of bankruptcy filing, such as having a bankruptcy flag on a credit report (Han, Keys, and Li 2013), and any ex-ante impacts of bankruptcy, such as over-borrowing, moral hazard in the workplace (White 2011), entrepreneurial risk-taking (Fan and White 2003, Armour and Cumming 2008), or the crowding out of formal insurance (Mahoney 2014). Using the same identification strategy, Dobbie and Song (forthcoming) find that Chapter 13 protection increases earnings and decreases mortality risk. ${ }^{4}$

There are three main contributions of this paper relative to Dobbie and Song (forthcoming). First, we estimate the effect of Chapter 13 protection on a broad range of financial outcomes that shed new light on the well-being of debtors. We employ a new dataset constructed for the purposes of this study that links over 175,000 bankruptcy filings to credit bureau records. These data allow us to examine the effects of consumer bankruptcy on post-filing adverse financial events, unsecured debt, secured asset holdings, credit access, and credit score. Moreover, because we observe detailed information on distressed borrowers both before and after bankruptcy, we are able to provide new evidence on the long-term consequences of excessive debt and the extent to which bankruptcy protection mitigates these adverse consequences. Second, we describe the characteristics of filers who are more likely to be affected by judge assignment. We find that young filers are more likely to be affected by a lenient judge assignment, but that there are no differences by baseline credit score or homeownership status. These results provide new evidence on the types of cases for which the

\footnotetext{
${ }^{3}$ The most commonly reported causes of bankruptcy are unexpected income or expense shocks. Sullivan, Warren, and Westbrook (2000) find that 67.5 percent of bankruptcy filers report job loss as a factor in filing for bankruptcy, 22.1 percent report family issues such as divorce, and 19.3 percent report medical expenses, with subsequent work suggesting a somewhat larger role for medical expenses (Domowitz and Sartain 1999, Warren, Sullivan, and Jacoby 2000, Himmelstein et al. 2009). Using data from the PSID, Fay, Hurst, and White (2002) find that households are also more likely to file for bankruptcy protection when there are larger financial benefits to doing so.

${ }^{4}$ Kling (2006) uses a similar empirical strategy to estimate the ex-post impact of sentence length on earnings, and subsequent papers have used similar methodologies to estimate the ex-post effects of foster care (Doyle 2007, 2008), juvenile incarceration (Aizer and Doyle forthcoming), corporate bankruptcy (Chang and Schoar 2008), temporaryhelp employment (Autor and Houseman 2010), and Disability Insurance (Maestas, Mullen, and Strand 2013, French and Song 2014).
} 
instrumental variables estimates are most likely to apply, and the types of filers who are most likely to be affected by changes in bankruptcy laws. Finally, we estimate a variety of non-experimental specifications that allows us to reconcile our estimates with a literature finding negative impacts of bankruptcy protection on post-filing finances (e.g. Han and Li 2007, 2011, Cohen-Cole, DuyganBump and Montoriol-Garriga 2013, Jagtiani and Li 2014).

In our empirical analysis, we find that Chapter 13 protection is largely successful in alleviating the most direct adverse consequences of excessive debt. Over the first five post-filing years, Chapter 13 protection decreases an index measuring adverse financial events such as civil judgment and repossession by 0.316 standard deviations, and significantly decreases seven of the eight individual measures of financial strain that compose the index. Chapter 13 protection has little impact on the amount of open unsecured debt, but the amount of debt in collections decreases by $\$ 1,315$, a 31.2 percent change from the dismissed filer mean of $\$ 4,217$. These results suggest that the marginal recipient of Chapter 13 protection reduces his or her unsecured debt through the bankruptcy system, while the marginal non-recipient is unable to prevent his or her unsecured debts from being sold to a third-party debt collector. Chapter 13 protection also increases the probability that the marginal recipient retains his or her home by 13.2 percentage points, a 36.4 percent increase from the dismissed filer mean of 36.3 percent, but there are no discernible effects on the probability of having a car.

Chapter 13 protection also has important impacts on credit access proxies and credit score, two financial outcomes not directly affected by bankruptcy protection. Over the first five post-filing years, Chapter 13 protection decreases revolving credit utilization by 16.1 percentage points, a 34.5 percent change from the dismissed filer mean, and decreases the number of non-mortgage inquiries by 0.293 , a 18.5 percent change from the dismissed filer mean. Chapter 13 protection increases the marginal recipient's credit score by 14.9 points over the first five post-filing years, a 2.6 percent increase from the dismissed filer mean.

We find suggestive evidence that protection from debt collectors and debt forgiveness are both important mechanisms that help explain our results, although large standard errors makes definitive conclusions impossible. To test the importance of protection from debt collectors, we compare treatment effects in states that do and do not allow wage garnishment. Consistent with there being significant costs of not being protected from debt collectors, we find large and statistically significant effects of Chapter 13 protection in states that allow wage garnishment, but small and imprecisely estimated effects in the four states that prohibit wage garnishment where creditors have fewer options to collect unpaid debts from dismissed filers. However, only one of eight differences is statistically significant due to large standard errors. To test the importance of debt forgiveness, we compare treatment effects in states with higher and lower Chapter 7 homestead exemption levels. Since Chapter 13 requires that creditors are repaid at least as much as they would have received in Chapter 7, homeowners that file for Chapter 13 in high exemption states are required to 
repay creditors less than filers in low exemption states. Consistent with the benefits of Chapter 13 protection increasing in the amount of debt that is forgiven, we find that the effects of Chapter 13 protection are larger for homeowners in states with high Chapter 7 exemption levels compared to homeowners in low Chapter 7 exemption states. However, once again, only two of eight differences are statistically significant due to the imprecision of our estimates.

The results reported in this paper stand in sharp contrast to the prior literature showing few benefits of filing for bankruptcy protection using non-experimental methods (e.g. Han and Li 2007, 2011, Cohen-Cole, Duygan-Bump and Montoriol-Garriga 2013, Jagtiani and Li 2014). Descriptive results show that the outcomes of both dismissed and granted bankruptcy filers deteriorate one to two years before filing. Outcomes for both groups remain depressed after filing, though much more so for dismissed filers. These descriptive trends suggest that non-experimental estimates are likely to be biased downwards due to selection into bankruptcy filing. Consistent with this scenario, we find that OLS estimates using a non-filer comparison group and within-individual estimates suggest negative effects of bankruptcy protection in our data. Conversely, OLS estimates using a dismissed filer comparison group are broadly consistent with our judge IV estimates, suggesting that selection into filing accounts for most of the bias in non-experimental specifications.

The remainder of the paper is structured as follows. Section I provides a brief overview of the consumer bankruptcy system in the United States. Section II describes our data and provides summary statistics. Section III describes our empirical strategy. Section IV estimates the impact of Chapter 13 bankruptcy protection on post-filing financial outcomes. Section V reconciles our estimates with the prior literature, and Section VI concludes. A data appendix provides additional information on the outcomes used in our analysis.

\section{Chapter 13 Bankruptcy Protection}

\section{A. Overview}

Under Chapter 13 bankruptcy, filers propose a three- to five-year plan to partially repay their unsecured debt in exchange for a discharge of the remaining unsecured debt, a hold on debt collection, and the retention of most assets. ${ }^{5}$ Chapter 13 requires filers to use all of their disposable income, defined as their predicted income less predicted expenses, to repay creditors. Creditors must receive at least as much as they would have received if the filer's assets were liquidated under Chapter 7, a requirement known as the "best interest of creditors" test. Chapter 13 filers are also required to fully repay priority claims, such as child support and alimony, unless the claimant agrees to a reduced payment. If a filer wants to keep any collateral securing a claim, he or she must keep up to date on all current payments and include any arrears in the repayment plan. The filer can also choose to

\footnotetext{
${ }^{5}$ During our sample period, Chapter 13 filers were able to choose the length of their repayment plan. In our data, granted filers took an average of 3.7 years to complete their plan.
} 
give up the collateral and discharge the remaining debt. Thus, Chapter 13 allows filers to avoid a costly home foreclosure and the repossession of a car by including any arrears in the repayment plan, with the original debt contract reinstated on the completion of the Chapter 13 repayment plan. In a sample of Delaware cases, 71 percent of filers included mortgage arrears in their repayment plans, 41 percent included car loans, and 38 percent included priority debt (White and Zhu 2010). Survey evidence suggests that approximately seventy percent of filers choose Chapter 13 in order to avoid foreclosure (Porter 2011).

Chapter 13 cases begin with the debtor filing the proposed repayment plan, a bankruptcy petition, a statement of financial affairs, a copy of his or her most recent tax return, executory contracts and unexpired leases, and schedules of current income, expenditures, and assets and liabilities. The bankruptcy trustee then holds a meeting with the debtor and any interested creditors in order to resolve problems with the proposed repayment plan. ${ }^{6}$ After this meeting, the bankruptcy judge decides whether the repayment plan is feasible and meets the standards for confirmation set forth in the Bankruptcy Code. If the judge confirms the repayment plan, the debtor makes biweekly or monthly payments to the trustee until the plan is complete. The judge may later dismiss or convert the case to Chapter 7 if the filer fails to make any payments, any post-filing domestic support obligations, or any post-filing taxes. If a Chapter 13 filing is dismissed, debtors may refile for either Chapter 7 or Chapter 13 after 180 days.

Debtors also have the option of filing under Chapter 7, which discharges unsecured debts and stops collection efforts in exchange for any non-exempt assets. Chapter 7 bankruptcy does not allow debtors to retain non-exempt assets or collateral securing delinquent debt. Our analysis focuses on the effects of Chapter 13 protection due to limited variation in the treatment of Chapter 7 cases. See Dobbie and Song (forthcoming) for additional details and a discussion of the differences between Chapter 7 and Chapter 13.

We estimate the benefits of Chapter 13 protection net the costs of repayment compared to the best outside option for the marginal dismissed filer. In practice, about 20 percent of dismissed Chapter 13 filers choose to refile under Chapter 7, while almost none refile under Chapter 13. Our judge IV estimates measure the effect of Chapter 13 protection relative to this counterfactual.

\section{B. Bankruptcy Judges}

Bankruptcy judges are federal judges appointed to 14-year terms by the Court of Appeals in their judicial district. There are a total of 94 federal bankruptcy courts in the United States, including at least one bankruptcy court in each state, the District of Columbia, and Puerto Rico. Each

\footnotetext{
${ }^{6}$ There is typically one Chapter 13 bankruptcy trustee who works with all judges in an office. If an office has a particularly high Chapter 13 caseload, judges may have their own Chapter 13 trustee. As a result, it is not possible to isolate the independent impact of trustees on the probability of receiving bankruptcy protection using our empirical methodology.
} 
bankruptcy court hears all cases originating from counties in its jurisdiction, and are often further divided into offices that hear all cases originating from a subset of counties in the court's jurisdiction. Bankruptcy judges often hear cases across multiple offices within their court, but only hear cases filed in their bankruptcy court. These cases are typically assigned to judges using a random number generator or a blind rotation system within each office. ${ }^{7}$

The assigned bankruptcy judge decides all matters connected to a case, including whether the repayment plan is feasible and meets the standards for confirmation set forth in the Bankruptcy Code. Common reasons for dismissal include the debtor being able to repay his or her debts without bankruptcy protection, the repayment plan repaying creditors too little, or the repayment plan being infeasible given the debtor's predicted income and expenses (Hynes 2004). In Section III, we discuss how we use systematic differences in the probability that a judge dismisses a filing to estimate the causal impact of bankruptcy protection. The variation in judge behavior that we measure is likely to be driven by differences in how judges interpret the above criteria.

Our empirical strategy also assumes that judges only impact future outcomes through the probability of receiving bankruptcy protection. This exclusion restriction would be violated if judges affect debtor outcomes in other ways, such as by providing financial counseling. The assumption that judges only systematically affect debtor outcomes through bankruptcy is fundamentally untestable, and our estimates should be interpreted with this potential caveat in mind. However, we argue that the exclusion assumption is not unreasonable in our setting. Despite the central role of bankruptcy judges, debtors typically have only limited interaction with the assigned judge. Chapter 13 filers appear before the bankruptcy judge at the plan confirmation hearing, but all other administrative aspects of the bankruptcy process are conducted by the bankruptcy trustee and not the judge. Thus, it seems unlikely that judges would significantly impact debtors other than through the probability of receiving Chapter 13 protection.

\section{Potential Benefits of Chapter 13 Protection}

There are at least three reasons that debtors may directly benefit from Chapter 13 bankruptcy protection. First, filing for and obtaining bankruptcy protection puts a hold on current and future debt collection efforts. ${ }^{8}$ Bankruptcy protection may therefore decrease the incentive to avoid repayment through strategies with significant deadweight costs, such as leaving the formal banking

\footnotetext{
${ }^{7}$ The median court in our sample is divided into three offices, with little systematic pattern to the number of offices in each court. There is considerable variation in the number of bankruptcy judges in each bankruptcy court and office, with courts serving more populous regions tending to have more judges. Of the 205 offices we observe in our data, 110 have only one Chapter 13 judge, 52 have two Chapter 13 judges, 25 have three Chapter 13 judges, and 18 have four or more Chapter 13 judges. See Dobbie and Song (forthcoming) for additional details.

${ }^{8}$ Dismissed filers receive a temporary stay on collections activity that lasts until the filing is dismissed. Estimates on debt collections activity are therefore likely to be biased downwards, at least in the short run.
} 
system to avoid seizure of assets or leaving the formal labor market to avoid wage garnishment. ${ }^{9}$ Second, Chapter 13 protection discharges any unsecured debts not repaid under the proposed plan, significantly improving a debtor's balance sheet. Third, Chapter 13 bankruptcy allows debtors to restructure secured debts such as a car or mortgage loan. Creditors are allowed to seize assets securing a delinquent loan if a debtor has not filed for bankruptcy protection or after a case has been dismissed, suggesting that Chapter 13 may allow debtors to retain important assets and avoid a potentially costly repossession or foreclosure.

There are also several potential indirect benefits of bankruptcy protection. Most importantly, bankruptcy protection may benefit debtors by increasing their access to credit through an improved balance sheet and fewer adverse collection events reported on a credit record. This may allow debtors to avoid more costly forms of credit, such as pawn or payday loans. Bankruptcy protection may also prevent any sharp drops in consumption that have important long-term consequences, such as becoming sick due to the lack of medical care. Finally, bankruptcy protection may increase economic stability by allowing debtors to avoid foreclosure or eviction.

There are also many reasons to believe that Chapter 13 protection will have little impact on debtors. First, it is possible that the bankruptcy process may exacerbate financial distress by forcing filers to devote all of their disposable income to the repayment plan. It is also possible that debtors are able to avoid most debt collection efforts at a relatively low cost or that collections strategies do not significantly affect most debtors. Finally, bankruptcy protection will have little impact if filers' financial distress stems from broader economic conditions, or immutable individual characteristics such as low human capital.

\section{Data}

\section{A. Data Sources and Sample Construction}

Our empirical analysis uses data from individual bankruptcy filings merged to credit bureau records from TransUnion. The bankruptcy records come from the 72 (out of 94) federal bankruptcy courts that allow full electronic access to their dockets. These data include approximately 75 percent of all filings during our sample period. Each record includes information on the filer's name, address, bankruptcy chapter, filing date, court, office, outcome, and the name of the judge and trustee assigned to the case.

\footnotetext{
${ }^{9}$ Creditors have a number of options to collect unpaid debts if a debtor has not filed for bankruptcy protection or after a case is dismissed, including wage garnishment, collection letters or phone calls, in-person visits at home or work, and seizing of assets through a court order. Debtors can make these collection efforts more difficult by ignoring collection letters and calls, changing their telephone number, or moving without leaving a forwarding address. Debtors can also leave the formal banking system to hide their assets from seizure, change jobs to force creditors to reinstate a garnishment order, or work less so that their earnings are not subject to garnishment. See Hynes, Dawsey, and Ausubel (2013) for additional discussion of the debt collection process.
} 
Following Dobbie and Song (forthcoming), we make four restrictions to the bankruptcy data. First, we drop filings from 110 offices that only have a single Chapter 13 bankruptcy judge and filings from counties that assign all cases to a single judge, as in both scenarios there is no variation in judge leniency that allows us to estimate the impact of Chapter 13 protection. Second, we drop office-by-year bins where a retiring judge's cases were reassigned with no documentation as to the original judge. Third, we restrict the sample to debtors who filed for Chapter 13 bankruptcy for the first time between June 2002 and December 2005, ensuring that we obtain at least five years of post-filing outcomes and at least one year of pre-filing baseline outcomes for all debtors. This restriction also ensures that filings occurred before the 2005 Bankruptcy Reform Act came into effect. Finally, we drop office-by-year-by-judge bins with fewer than ten cases where we are unlikely to be able to accurately measure judge leniency. These sample restrictions leave us with 253,863 filings.

We matched these 253,863 filings to credit bureau records from TransUnion using name and address at the time of filing. We were able to successfully match 68.9 percent of our estimation sample to the TransUnion data. Our match rate is similar to Finkelstein et al. (2012), who matched 68.5 percent of Oregon Medicaid applicants to TransUnion data using name, address, and date of birth. The probability of being matched to the credit report data is not significantly related to judge leniency (see Panel F of Table 1).

The TransUnion data are available from June 2002 to June 2010. We observe each individual in the credit bureau data annually in June. The TransUnion data are derived from public records, collections agencies, and trade lines data from lending institutions. The data also include geographic location at the ZIP code-level and age. No other demographic information is available at the individual level. See Avery et al. (2003) and Finkelstein et al. (2012) for additional details on the TransUnion data.

Our estimation sample includes the 253,863 filings matched to at least one post-filing year of credit bureau data. This sample consists of 175,076 filers from 39 offices and 29 bankruptcy courts. The sample includes 348 office-by-year-by-judge observations - the level of variation that drives our empirical design. The number of cases in each office-by-year-by-judge bin ranges from 31 to 2,040, with a median of 799. Appendix Table 1 provides additional details on each of the offices in our estimation sample.

\section{B. Measures of Financial Outcomes}

We use the linked dataset to estimate the impact of Chapter 13 bankruptcy protection on financial strain, unsecured debt, asset holdings, credit access, and credit score. This section briefly describes how we construct the measures used in our main analysis. The data appendix provides additional details on all of the measures used in our analysis. 
Financial strain is measured using indicators for delinquency, creditor charge-offs, collections, bankruptcy, foreclosure, civil judgments, liens, and repossessions within the last 12 months. Delinquency occurs when at least one trade is reported 30 or more days past due, and is our most common measure of financial strain. Credit charge-offs typically occur after 180 days of non-payment on an account, implying that this measure therefore captures a more severe form of non-payment than delinquency. Collections indicate that at least one account has been transferred to a third-party collections agency or is in the process of collection at some point in the last 12 months. Our collections measure does not include debts sent to collection agencies that do not report to credit bureaus, and therefore represents a lower bound on total collections activity. Bankruptcy indicates a new filing in the last 12 months. Foreclosures indicate any foreclosure related action during the last 12 months, including a foreclosure being initiated, a foreclosure being discontinued, and a foreclosure being redeemed. The foreclosure measure used in this paper is therefore more inclusive than the foreclosure measure used in Dobbie and Song (forthcoming), which only included foreclosure sales and transfers. Civil judgments include all wage garnishment orders, liens against property, and levies on checkings or savings accounts in the last 12 months. Civil judgments are often difficult and costly to obtain, meaning that this measure is likely proxying for particularly large unpaid bills. Liens indicate at least one public records claim on a lien in the past 12 months. Public record liens include federal and state tax liens, hospital liens, and judicial liens. Repossession indicates that a creditor has attempted to take back a secured asset, such as a car or boat, in the last 12 months.

Each financial strain measure is the average of five indicator variables for having experienced the listed event from the filing year to the fifth post-filing year, with two exceptions. We measure both charge-offs and new bankruptcies from the first full post-filing year to fifth year after filing to exclude the mechanical effect of the original Chapter 13 filing on these outcomes in the year of filing. Appendix Table 2 reports results using the number of adverse events in the first five post-filing years and the cumulative probability of an event occurring at least once in the first five post-filing years for each of the eight adverse financial events in our data.

We also report results using a financial strain index, a summary index of these eight adverse events designed to broadly capture financial distress associated with collections activity. Following Fryer and Katz (2013), for each post-filing year, we first standardize each component in the financial strain index using the mean and standard deviation of the component for the dismissed filer group in the baseline year. Next, we sum the eight components in each year, restandardizing using the mean and standard deviation of the index for the dismissed filer group in the baseline period. To exclude the mechanical effect of filing on charge-offs and new bankruptcies in the year of filing, the financial strain index in the year of filing is composed of the other six measures of adverse financial events. Finally, we average these annual index measures over the first five post-filing years. Because each of the financial strain components represent adverse events that negatively impact access to 
credit, a higher index represents worse outcomes throughout.

Unsecured debt and collections activity are measured using the current balance of open revolving loans, and the amount of debt currently in collections. Revolving loans includes all current bank cards, retail cards, and check credit accounts. Collections debt include all loans that have been transferred to a collection agency or that are in the process of collection. Following the above discussion, our measure of collections debt is likely a lower bound. Our unsecured debt data do not include information on some non-bank and non-retail forms of unsecured credit, such as pawn and payday loans. The data also do not include information on the cost of revolving debt. We are therefore unable to estimate the impact of Chapter 13 on these outcomes.

Retention of secured assets is measured using indicators for having an open mortgage loan within the past 12 months and having an open auto loan within the past six months, and the current balance of all open mortgages and open auto loans. All of the debt balance measures are captured in June of each year. Having an active mortgage or auto loan proxies for ownership of these assets, but is an underestimate of actual ownership as some filers have likely fully paid off their mortgage or auto loans.

We measure credit access using the total utilization on revolving accounts, and the number of non-mortgage inquiries in the last six months. TransUnion does not provide credit line information for each category of non-mortgage debt, so we proxy for credit supply using revolving trades, the largest category of non-mortgage credit among all credit users and our estimation sample. Revolving trades include any bank card accounts, retail accounts, and check credit accounts. Results are qualitatively similar using bank card trades, a subset of revolving trades. Utilization is defined as the current balance divided by the credit limit, where TransUnion measures the credit limit using either the reported credit limit, or the highest amount ever owed on an account if the credit limit is unreported. Avery et al. (2003) discuss this imputation procedure, concluding that the credit limit variable is likely a lower bound. Accordingly, utilization measures likely reflect an upper bound for accounts where the credit limit is imputed. Importantly, estimates using utilization may be biased if Chapter 13 protection impacts the highest amount ever owed on an account, as credit limits will appear higher for these individuals. Our utilization estimates should be interpreted with this potential measurement bias in mind. Our second measure of credit access is the number of non-mortgage inquiries. Inquiries are made to ensure that an applicant for credit, apartment rental, insurance, or employment meets minimum standards, and is considered a proxy for excess credit demand.

Credit score is measured using an ordinal credit score variable calculated by TransUnion to capture credit risk. The TransUnion credit score variable is used by creditors to determine the price and eligibility for credit, and is similar to the FICO score commonly referenced in the consumer finance literature. Our credit score variable should therefore be interpreted as a summary measure 
of a debtor's financial risk, and incorporates many of the potential effects on the outcomes discussed above. We report estimates using the scale provided by TransUnion.

\section{Descriptive Statistics}

Table 1 presents summary statistics for our data. Column 1 reports summary statistics for a random sample of the population of credit users in the TransUnion database. ${ }^{10}$ Column 2 reports summary statistics for individuals in this random sample that file for bankruptcy protection during our sample period. The TransUnion data does not report chapter of filing, so these individuals include a mix of Chapter 7, Chapter 11, Chapter 12, and Chapter 13 filers. Because very different types of individuals file under various bankruptcy chapters, bankruptcy filers in the national sample are likely to differ in substantial ways from Chapter 13 filers. ${ }^{11}$ Columns 3 and 4 report summary statistics for Chapter 13 filers in our estimation sample assigned to judges with below and above median judge leniency as defined in Section III.

Bankruptcy filers are younger and more likely to own a home than the typical credit user in the United States. The typical bankruptcy filer in the national sample is 43.7 years old, compared to 48.5 years old for all credit users. Fifty-two percent of bankruptcy filers own a home. In comparison, 47.0 percent of all credit users own a home. In our estimation sample, 65.5 percent of Chapter 13 filers are homeowners and the average age is 44.8 years old.

Perhaps not surprisingly, bankruptcy filers are far more likely to suffer an adverse financial event than the typical credit user even before filing. In the national sample, 41.3 percent of bankruptcy filers have at least one delinquency before filing, 29.6 percent have at least one debt in collections, 18.8 percent have at least one creditor charge-off, 3.4 percent have at least one civil judgment, 1.0 percent have experienced a foreclosure, 1.1 percent have at least one property lien, and 1.2 percent have at least one repossession. Chapter 13 filers in our estimation sample are even more likely to have suffered an adverse financial event before filing compared to the typical credit user, with 67.7 percent having had a delinquency in the past 12 months, 46.3 percent having a debt in collections, 30.9 percent having a charge-off, 6.3 percent having a judgment, 5.1 percent having a foreclosure, 2.1 percent having a lien, and 2.1 percent having a repossession. In comparison, only 14.8 percent of all credit users have a delinquency in the past 12 months, 13.7 percent have a debt in collections, 6.5 percent have a charge-off, 0.9 percent have a judgment, 0.3 percent have a foreclosure, 0.4 percent have a lien, and 0.3 percent have a repossession.

\footnotetext{
${ }^{10}$ See Dobbie and Goldsmith-Pinkham (2014) for additional details on the credit user sample. The data contain approximately two percent of all credit users in the United States during this time period.

${ }^{11}$ The TransUnion data do not provide information on the date of bankruptcy filing or the chapter of bankruptcy, but each calendar year pull provides information on the number of bankruptcy filings in the last 12 months. From this bankruptcy filing flag, we define bankruptcy filers as those individuals who filed for bankruptcy for the first time in the last 12 months based on credit report data between 2003 and 2006. Individuals whose bankruptcy flag is turned on in multiple years between 2003 and 2006 are excluded.
} 
Bankruptcy filers also have significantly higher unsecured debt and collections activity compared to the typical credit user. Bankruptcy filers in the national sample have $\$ 13,083$ in revolving debt and $\$ 1,432$ of debt in collections. Chapter 13 filers in our estimation sample have $\$ 10,460$ in revolving debt and $\$ 2,460$ of debt in collections. In comparison, the typical credit user has $\$ 6,011$ in revolving debt and $\$ 601$ of debt in collections.

Bankruptcy filers are more likely to have an open mortgage than the typical credit user. In the national sample, 43.4 percent of bankruptcy filers have at least one open mortgage, compared to 36.7 percent for all credit users. In our estimation sample, 57.9 percent of Chapter 13 filers have at least one open mortgage. Note that active mortgage rates are generally lower than homeownership rates in both the national sample and estimation sample, suggesting that approximately seven to ten percent of homeowners have already paid off their mortgages.

While bankruptcy filers in the national sample are more likely to have a mortgage, they have mortgage balances that are $\$ 2,612$ lower than the typical credit user, while Chapter 13 filers in our estimation sample have mortgage balances that are $\$ 12,615$ more than the typical credit user. Home mortgage balances are likely higher among Chapter 13 filers than bankruptcy filers in the national sample because national bankruptcy filers comprise those who file under Chapter 7 as well as Chapter 13, and Chapter 7 filers are less likely to be homeowners.

Bankruptcy filers are also 17.1 percent more likely to have an open auto loan compared to the typical credit user, with Chapter 13 filers in our estimation sample 19.1 percent more likely to have an active auto loan than the typical credit user. Accordingly, bankruptcy filers in the national sample have auto balances that are $\$ 3,412$ more than the typical credit user. Chapter 13 filers in our estimation sample have auto balances $\$ 3,892$ more than the typical credit user.

Bankruptcy filers in the national sample have higher utilization on revolving accounts and more credit inquiries than the typical credit user, suggesting that bankruptcy filers have excess credit demand conditional on credit supply. Specifically, bankruptcy filers in the national sample have utilization rates that are 35.9 percentage points higher than the average credit user, and also have 1.0 more non-mortgage inquiries in the last six months than the typical credit user. In our estimation sample, Chapter 13 filers have 45.4 percentage points higher utilization on revolving accounts than the typical credit user, and 1.5 more non-mortgage inquiries.

Bankruptcy filers also have lower credit scores than the typical credit user in the United States. Average pre-filing credit scores are 630.0 for bankruptcy filers in the national sample. In comparison, average credit scores are 739.5 for all credit users. In our estimation sample, the average credit score is 580.7 . 


\section{Research Design}

Consider a model that relates post-filing outcomes such as credit score to the receipt of Chapter 13 bankruptcy protection:

$$
y_{i t}=\alpha+\beta \mathbf{X}_{i}+\gamma \text { Bankruptcy } y_{i}+\varepsilon_{i t}
$$

where $i$ denotes individuals, $t$ is the year of observation, $\gamma$ is the causal impact of bankruptcy protection, $\mathbf{X}_{i}$ includes controls such as age and lagged outcomes, and $\varepsilon_{i t}$ is noise. Our key empirical problem is that OLS estimates of equation (1) may be biased if bankruptcy protection is correlated with the unobservable determinants of later outcomes, explored further in Section V.

We estimate the impact of Chapter 13 protection on debtors using judge leniency as an instrument for bankruptcy protection. Our empirical strategy exploits the fact that judges are randomly assigned to filings, and that those bankruptcy judges have differing tendencies to grant Chapter 13 protection. In this specification, we interpret any difference in post-filing outcomes as the causal effect of the change in the probability of receiving bankruptcy protection operating through judge assignment. The second stage estimating equation is:

$$
y_{i t}=\alpha+\alpha_{o t}+\beta \mathbf{X}_{i}+\gamma \text { Bankruptcy } y_{i}+\varepsilon_{i t}
$$

where $\alpha_{o t}$ are office-by-filing-month fixed effects and $\mathbf{X}_{i}$ includes baseline age bins, homeownership, financial strain, revolving, mortgage, auto, and collections debt, indicators for open mortgage and open auto loans, revolving utilization, non-mortgage inquiries, and credit score. $\mathbf{X}_{i}$ also includes indicators for missing age and baseline characteristics.

The corresponding first stage estimating equation associated with equation (2) is:

$$
\text { Bankruptcy }_{i t}=\alpha+\alpha_{o t}+\beta \mathbf{X}_{i}+\delta \sigma_{j}+\varepsilon_{i t}
$$

where $\sigma_{j}$ is the systematic component of judge behavior and $\delta$ represents the impact of judge behavior on the probability of receiving bankruptcy protection. We cluster standard errors at the office level in both the first and second stage regressions to account for any serial correlation across

filers at the level of randomization. Results are qualitatively similar if we cluster at the office-byjudge or office-by-filing-month level.

Following the previous literature (e.g. Kling 2006, Chang and Schoar 2008, Doyle 2007, 2008, Autor and Houseman 2010, French and Song 2014, Aizer and Doyle forthcoming, Maestas, Mullen, and Strand 2013, and Dobbie and Song forthcoming), we define judge leniency $Z_{i o j}$ as the leaveone-out fraction of filings granted by judge $j$ in office $o$ minus the leave-one-out fraction granted in 
office $o$ :

$$
Z_{i o j}=\frac{1}{n_{o j}-1}\left(\sum_{k=1}^{n_{o j}}\left(B_{k}\right)-B_{i}\right)-\frac{1}{n_{o}-1}\left(\sum_{k=1}^{n_{o}}\left(B_{k}\right)-B_{i}\right)
$$

where $i$ again denotes individuals, $o$ denotes offices, $j$ is the assigned judge, $B_{i}$ is an indicator for receiving bankruptcy protection, $n_{o j}$ is the number of cases seen by a judge in office $o$, and $n_{o}$ is the number of cases seen by an office. We calculate judge leniency using all filings in the full sample of filings, including those not matched to TransUnion credit records.

Our preferred measure of judge leniency uses the final decision on each bankruptcy filing, not whether a plan is initially confirmed or dismissed. We focus on this measure of judge leniency for two reasons. First, the resulting two-stage least squares estimates can be interpreted as the causal effect of receiving bankruptcy protection, which has clearer policy implications than plan confirmation. Second, we do not observe the reason for case dismissal in our data, and are therefore unable to measure plan confirmation directly. In Section IV.G, we present estimates that use judge leniency measured over the first 90 days, a proxy for plan confirmation. These results are nearly identical to our preferred estimates discussed below. See Section IV.G for additional details on this alternative measure of judge leniency and other robustness checks.

Consistent with Dobbie and Song (forthcoming), we find considerable variation in the treatment of Chapter 13 cases within an office. ${ }^{12}$ The standard deviation of $Z_{i o j}$ is 0.025 for Chapter 13 filers in our sample. There is also significant persistence in our measure of judge behavior. Appendix Figure 1 plots current and lagged judge discharge rates, with each point representing a separate judge-by-office-by-year observation. Discharge rates are highly correlated across time, with an OLS regression relating each judge-by-office-by-year discharge rate to the lagged discharge rate yielding a coefficient of 0.902 . These results suggest that we are capturing systematic differences in judge behavior, not random year to year noise.

Using our measure of judge leniency $Z_{i o j}$ as an instrument for the receipt of Chapter 13 bankruptcy protection, two-stage least squares estimates from equation (2) measure the local average treatment effect of Chapter 13 protection for filers whose bankruptcy outcomes are altered by judge assignment. Three conditions must hold to interpret these estimates as the average causal impact of bankruptcy protection: (1) judge assignment is associated with bankruptcy protection, (2) judge assignment only impacts debtor outcomes through the probability of receiving bankruptcy protection, and (3) the impact of judge assignment on the probability of receiving bankruptcy protection is monotonic across filers.

Appendix Figure 2 tests the first assumption by plotting average discharge against our leave-oneout measure of judge leniency. The estimation sample includes first-time filers between 2002 and

\footnotetext{
${ }^{12}$ See Sullivan, Warren, and Westbrook (1994) and Norberg and Compo (2007) for additional discussion on the variation in bankruptcy judge behavior.
} 
2005 in the 39 offices in the 29 courts that randomly assign Chapter 13 filings to judges. Appendix Figure 2 is constructed by calculating the mean residuals from a regression of an indicator for receiving Chapter 13 protection on office-by-filing-month fixed effects. For ease of interpretation, we add the mean discharge rate to the mean residual in each judge-by-year bin. The plotted line and corresponding coefficient show the best linear fit estimated on the underlying individual-level data, controlling for office-by-filing-month fixed effects and with standard errors clustered at the office level. Table 2 presents analogous individual-level estimates with and without controls.

Appendix Figure 2 and Table 2 indicate that judge leniency is highly predictive of the probability of receiving bankruptcy protection. With no controls, a one percentage point increase in $Z_{i o j}$ increases the probability that a debtor receives bankruptcy protection by 0.889 percentage points. Controlling for all baseline characteristics in column 6, our measure of judge leniency remains highly predictive of the probability of receiving bankruptcy protection, with a one percentage point increase in $Z_{i o j}$ increasing the probability that a debtor receives bankruptcy protection by 0.811 percentage points. Thus, a one standard deviation (2.5 percentage point) increase in judge leniency increases the likelihood of receiving bankruptcy protection by about 2.0 percentage points, corresponding to a 4.5 percent change from the mean discharge rate of 44.6 percent.

Consistent with the first stage results in Dobbie and Song (forthcoming), the probability of receiving Chapter 13 protection does not increase one-for-one with our measure of judge leniency, likely because of measurement error that attenuates the effect toward zero. For instance, the accuracy of our leave-one-out measure will be reduced if judge leniency drifts over the course of the year or fluctuates with case characteristics. Nevertheless, our first stage results confirm that our measure of judge leniency is highly predictive of case outcomes.

The coefficients on our baseline controls are of independent interest for understanding the types of individuals more or less likely to receive Chapter 13 protection. The probability of receiving bankruptcy protection is increasing in filer age. Homeowners are also more likely to receive Chapter 13 protection than non-homeowners. The probability of receiving Chapter 13 protection is decreasing in most measures of financial strain and the amount of debt in collections. The probability of receiving bankruptcy protection is also decreasing in mortgage and auto debt, although individuals with open mortgage and auto loans are more likely to receive Chapter 13 protection. Conversely, filers with higher unsecured debt are more likely to receive bankruptcy protection, as are filers with more revolving accounts. Finally, the probability of receiving Chapter 13 is decreasing with the number of credit inquiries in the last six months, and increasing with credit score.

Following Doyle (2008), we also present first stage results for different subsamples to shed light on the characteristics of filers who are more likely to be affected by judge assignment. In the case of a binary instrument, the relative likelihood that a complier has a given characteristic is equal to the first-stage coefficient for that group divided by the first-stage coefficient for the full sample. Similar 
logic applies to the case of a continuous instrument. Given that filers likely differ in how much they benefit from Chapter 13 protection, these results provide new evidence on the types of cases for which the instrumental variables estimates are most likely to apply, that is, those filers for whom judges most disagree on whether to grant bankruptcy protection. These results also provide insight into the likely impacts of debt-relief policy interventions that target different types of debtors.

Appendix Table 3 shows the first-stage estimates for subgroups of interest. We also present the ratio of the subgroup first-stage coefficient to the overall first-stage coefficient from column 6 of Table 2. The most striking first-stage result is for filers 25 to 39 years old at the time of filing, who have a first stage coefficient that is 16.5 percent higher than the overall first stage, although the ratio is not significantly different from one due to variability in the data. Conversely, filers who are 60 and up have a first-stage coefficient that is only 52.3 percent of the overall first stage, significantly different from one. First-stage results are not substantially different between filers with below and above median baseline credit scores, and by baseline homeownership status. These results suggest that young filers are most likely to be affected by a lenient judge assignment, indicating greater judicial disagreement over these types of filers.

Our second identifying assumption is that judge assignment only impacts debtor outcomes through the probability of receiving bankruptcy protection. This assumption would be violated if judge leniency is correlated with unobservable determinants of future outcomes. We partially test this assumption by assessing whether observable filer characteristics differ based on whether filers are assigned to a judge with either a high or low propensity to grant Chapter 13 protection. Following Aizer and Doyle (forthcoming), columns 3 and 4 of Table 1 present summary statistics separately for filers assigned to judges with above and below median leniency. Column 5 reports results from a series of OLS regressions of each observable filer characteristic on an indicator for being assigned to a judge with above median leniency and office-by-filing-month fixed effects with standard errors clustered by office. Consistent with our identifying assumptions, there is only one statistically significant difference in the 26 variables we consider.

Our third identifying assumption is that there is a monotonic impact of judge assignment on the probability of receiving bankruptcy protection. The monotonicity assumption implies that being assigned to a more (less) lenient judge does not decrease (increase) the likelihood of receiving Chapter 13 protection. Following Dobbie and Song (forthcoming), we partially test the validity of the monotonicity assumption by examining how judges treat filings from observably different filers. Any significant differences in the way that judges treat these filings would suggest that the monotonicity assumption is violated. Appendix Figure 3 plots judge leniency measures calculated separately by age at filing, baseline credit score, baseline home ownership, and baseline financial strain. Each plot reports the coefficient and standard error from an OLS regression relating each measure of judge leniency. Consistent with our monotonicity assumption, we find that judge tendencies are 
very similar across observably different filers.

In unreported results, we also examine whether measures of judge leniency for subcategories of individuals, such as young versus old filers, are additionally predictive beyond the average leniency for a judge. If the monotonicity assumption holds, these subgroup specific measures of judicial leniency should not be predictive of case outcomes after we condition on average judge leniency. Consistent with our monotonicity assumption, we find that only the average measure of judge leniency is a statistically significant predictor of case outcomes. None of the subgroup specific measures of judicial leniency are statistically significant, and a joint test of significance yields a p-value of 0.776. Using principal component analysis, we also find no evidence of clustering in each judge's subgroup specific leniency measures. These results further suggest that judicial leniency does not vary across different types of filers. None of our results suggest that the monotonicity assumption is likely to be invalid in our setting.

\section{Results}

We begin by exploring the impact of Chapter 13 protection on financial strain associated with debt collection, the amount of unsecured debt, and retention of assets. We then estimate the indirect effects of Chapter 13 protection on credit access and credit score. We conclude by examining the most likely mechanisms driving our results and testing the robustness of our empirical design.

\section{A. Financial Strain}

Panel A of Table 3 reports two-stage least squares estimates for our financial strain index and each individual component of the index. As discussed above, each individual component of the financial strain index is the average of five indicator variables for having experienced the listed event from the filing year to the fifth post-filing year. For all of our financial strain measures, our estimates should be interpreted as the average change in the probability of experiencing an event each year. The financial strain index combines all eight adverse financial events, as described previously. Our estimation sample consists of Chapter 13 bankruptcy filers originating from offices that randomly assign filers to judges between 2002 and 2005 that are linked to the credit report data in the year of filing. Column 1 reports the mean post-filing average probability for each event for dismissed filers. Column 2 presents two-stage least squares estimates using our leave-one-out measure of judge leniency controlling only for office-by-filing-month fixed effects. Column 3 adds controls for baseline age bins, homeownership, financial strain, revolving, mortgage, auto, and collections debt, indicators for open mortgage and open auto loans, revolving utilization, non-mortgage inquiries, and credit score. Details on these measures can be found in the data appendix. We report standard errors clustered at the office level throughout. 
We find that Chapter 13 significantly improves financial well-being by reducing the likelihood of adverse financial events and creditor actions. Over the first five post-filing years, Chapter 13 protection decreases the marginal recipient's level of financial strain by 0.316 to 0.369 standard deviations. Turning to each individual component, we find that Chapter 13 protection decreases the marginal recipient's probability of having a debt in collections by 14.9 to 20.1 percentage points, a 25.5 to 34.4 percent decrease from the dismissed filer mean of 58.4 percent. Credit charge-offs decrease by 6.5 to 6.7 percentage points, a 30.0 to 31.0 percent decrease from the dismissed filer mean of 21.6 percent. Subsequent bankruptcy filings (of all chapters) decrease by 6.4 percentage points, a 58.7 percent decrease from the dismissed filer mean of 10.9 percent. Foreclosures decrease by 1.6 to 3.0 percentage points, a 22.9 to 42.8 percent decrease from the dismissed filer mean of 7.0 percent. Creditor judgments decrease by 3.1 to 3.9 percentage points, a 46.9 to 59.0 percent decrease from the dismissed filer mean of 6.6 percent. Liens decrease by 3.4 percentage points, a 100.0 percent decrease from the dismissed filer mean of 3.4 percent. Repossessions decrease by 1.5 percentage points, a 78.9 percent decrease from the dismissed filer mean of 1.9 percent. Conversely, there is no impact of Chapter 13 protection on delinquency, defined as the probability of any trade being at least thirty days past due. ${ }^{13}$

Table 4 presents two-stage least squares results from our preferred specification separately by age, baseline credit score, and baseline homeownership. Chapter 13 reduces financial strain by 0.416 standard deviations for homeowners compared to just 0.165 standard deviations for nonhomeowners, though the difference is not statistically significant. There are no economically or statistically significant differences by age or baseline credit score.

Consistent with Dobbie and Song (forthcoming), we find that our results are driven by a deterioration of outcomes among dismissed filers rather than gains among granted filers (see Appendix Figure 4). Taking repossession as a illustrative example, we see that both dismissed and granted filers are more likely to experience a repossession than non-filers even before filing. In the four years before filing, repossession rates average 0.7 percent and 1.4 percent among granted and dismissed filers, respectively. Repossession rates increase to 1.1 percent for granted filers and 1.6 for dismissed filers in the year before filing, before peaking at 2.4 and 3.4 percent, respectively, in the year of filing. Repossession rates for dismissed filers remain elevated at approximately 1.4 percent throughout our sample period, while the rates for granted filers fall to about 0.5 percent, comparable to non-filers. These results are consistent with bankruptcy protection mitigating the long-term consequences of financial shocks that might otherwise harm debtors, but not conferring benefits in the absence of a financial shock.

We conclude this section by comparing the magnitude of our two-stage least squares estimates to

\footnotetext{
${ }^{13}$ Panel A of Appendix Table 4 presents additional financial strain results. We find that Chapter 13 protection decreases both the number of paid and unpaid collections, but has no impact on the number of medical collections. The decrease in judgments is due to a decrease in unpaid judgments.
} 
the deterioration of outcomes for dismissed filers. This calculation provides a back-of-the-envelope approximation of the extent to which Chapter 13 protection mitigates the adverse consequences of financial distress. Specifically, we calculate the change in outcomes for dismissed filers by subtracting the average post-filing outcomes for the first five post-filing years from the pre-filing outcomes in the third to fourth years pre-filing. This calculation implies that Chapter 13 protection mitigates approximately 91.1 percent of the deterioration in the financial strain index. For our other financial strain measures, Chapter 13 protection mitigates approximately 28.6 percent of the deterioration in the probability of having a foreclosure and approximately 100 percent of the potential deterioration in the probability of having collections debt, a charge-off, a new bankruptcy, a judgment, a lien, and a repossession.

\section{B. Unsecured Debt and Collections}

Panel B of Table 3 reports two-stage least squares estimates on open unsecured debt and collections debt. Each dependent variable is the average amount of debt reported in each category. We report results using the year of filing to the fifth post-filing year.

There is little impact of Chapter 13 protection on open unsecured debt. Point estimates are small and not statistically different from zero. However, the marginal recipient of Chapter 13 has $\$ 1,315$ to $\$ 1,842$ less debt in collections, a 31.2 to 43.6 percent decrease from the dismissed filer mean of $\$ 4,217$. The impact of Chapter 13 on collections debt is higher for filers with high baseline credit scores, but does not vary by age or homeownership. ${ }^{14}$

Comparison of means shows that open unsecured debt falls for both granted and dismissed filers post-bankruptcy. Collections debt increases for both groups before filing, but falls to pre-filing levels for granted filers only in the post-filing years. Taken together with our above results, these trends suggest that the marginal recipient of Chapter 13 protection reduces his or her unsecured debt through the bankruptcy system, while the marginal non-recipient is unable to prevent his or her unsecured debts from being sold to a third-party debt collector. Using these trend results, we estimate that Chapter 13 protection mitigates approximately 63.7 percent of the potential increase in collections debt.

\section{Secured Assets}

Panel C of Table 3 reports two-stage least squares estimates for the probability of having an open mortgage, the average amount of mortgage debt, the probability of having an open auto loan, and the amount of auto debt. We report results using the year of filing to the fifth post-filing year.

\footnotetext{
${ }^{14}$ Panel B of Appendix Table 4 presents results for student debt, a form of unsecured debt that is not discharged under Chapter 13 protection. We find no impact of Chapter 13 on active or deferred student debt.
} 
We find that Chapter 13 protection significantly increases the probability of having a mortgage by 11.0 to 13.2 percentage points, a 30.3 to 36.4 percent increase from the dismissed filer mean of 36.3 percent. Chapter 13 protection also increases the marginal recipient's mortgage debt by $\$ 12,196$ to $\$ 14,267$, a 45.4 to 53.2 percent increase from the dismissed filer mean of $\$ 26,833$. Unsurprisingly, the impact of Chapter 13 on both homeownership and mortgage debt is higher for baseline homeowners. Effects are also larger for filers who are 60 or older at the time of filing.

The increase in mortgage debt may be the result of dismissed filers decreasing their mortgage debt by downsizing or becoming renters, or by granted filers increasing their mortgage debt by buying a new home. Panel $\mathrm{C}$ of Appendix Table 4 sheds light on this issue by estimating the impact of Chapter 13 protection on the probability of living in the same residence, the probability of moving to a rental, and the probability of moving to a home. Each dependent variable is measured in the fifth post-filing year, with identical results for earlier years. Chapter 13 protection increases the probability of staying in the same residence by 25.0 to 27.0 percentage points and decreases the probability of moving to a rental by 25.0 to 26.7 percentage points. These results are consistent with Chapter 13 decreasing the probability that filers sell or lose their homes.

Comparison of means provides additional evidence on this issue. The probability of having a mortgage increases in the years before filing for both granted and dismissed filers, peaking the year before filing at 59.8 percent and 56.2 percent, respectively. For granted filers, the probability of having a mortgage falls modestly after filing to around 45 percent. For dismissed filers, the probability of having a mortgage falls all the way to 21.8 percent by the fifth year after filing. These trend results suggest that Chapter 13 protection alleviates more than 100 percent of the potential fall in homeownership rates.

We also explore the impact of Chapter 13 protection on whether a debtor has an open auto loan and average auto debt. Because at least some car owners do not have an open car loan, our measures of car ownership are lower bounds. Chapter 13 protection does not have a statistically significant effect on the probability of having a car loan or on auto debt. In Appendix Figure 4, we find that the probability of having a car loan falls in the year of filing for both granted and dismissed filers, suggesting that most debtors give up their cars. These results suggest that the retention of a home may be a more important priority for Chapter 13 filers. This interpretation is consistent with survey results showing that over seventy percent of dismissed filers choose to file under Chapter 13 bankruptcy to avoid foreclosure (Porter 2011).

\section{Credit Access}

Panel D of Table 3 reports two-stage least squares estimates for the total utilization on revolving accounts, and the number of non-mortgage inquiries. Each dependent variable is a five-year average from the year of filing to the fifth post-filing year. As discussed previously, while these outcomes have 
a less clear economic interpretation than our other outcomes, they are still suggestive of potential economic benefits to bankruptcy protection.

We find that Chapter 13 protection decreases revolving credit utilization, as measured by the balance to credit limit ratio. These revolving trades include bank credit cards, retail credit cards and check credit accounts. Revolving accounts are the most common type of credit accounts, representing 63 percent of all credit accounts, and about 71 percent of all open accounts (Avery et al. 2003). Utilization decreases by 15.1 to 16.1 percentage points, a 32.3 to 34.5 percent decrease from the dismissed filer mean of 46.7 percent. Chapter 13 protection also decreases the number of non-mortgage inquiries in the past six months by 0.293 to 0.410 , a 18.5 to 25.9 percent decrease from the dismissed filer mean of 1.584. The impact of Chapter 13 on credit utilization is larger among younger filers, and the impact on non-mortgage inquiries is larger among baseline homeowners. Overall, these results suggest that Chapter 13 protection increases credit access. ${ }^{15}$

However, a comparison of means shows that utilization rates and non-mortgage inquiries fall (i.e. improves) for both granted and dismissed filers after filing, with larger falls for granted filers. For dismissed filers, average revolving utilization decreases by 19.3 percent and average non-mortgage inquiries decrease by 0.8 from the pre- to post-filing periods. These results are consistent with the pre-filing levels of credit usage being unsustainable for all filers. This suggests that our two-stage least squares estimates may be more correctly interpreted as Chapter 13 protection decreasing unmet credit demand, rather than increasing credit supply. Following our earlier back-of-the-envelope calculations, our estimates suggest that Chapter 13 protection further augments the fall in utilization by an additional 78.2 percent, and further augments the fall in the number of inquiries by an additional 36.5 percent.

\section{E. Credit Score}

Panel E of Table 3 reports two-stage least squares estimates for credit score, an aggregate measure of financial health or credit risk. The dependent variable is the mean credit score from the year of filing to the fifth post-filing year.

There is a large and precisely estimated impact of Chapter 13 bankruptcy protection on postfiling credit score. The two-stage least squares results with no controls suggest that Chapter 13 protection increases the marginal recipient's post-filing credit score by 28.5 points, a 5.0 percent increase from the dismissed filer mean of 565.4 points. With controls, the estimated impact is 14.9 points, a 2.6 percent increase from the dismissed filer mean. The smaller point estimate when baseline controls are included is likely due to baseline credit scores being modestly different for

\footnotetext{
${ }^{15}$ The increase in credit access is most likely the results of improved financial health documented above, as opposed to any limits on future bankruptcy filing. While discharged Chapter 13 filers have to wait six years before filing under Chapter 7, filers are still in the process of making plan payments during three to five years post-filing.
} 
filers assigned to more and less lenient judges in our matched sample. Estimates are larger for homeowners and filers with higher baseline credit scores.

Consistent with our earlier results, a comparison of means shows that credit scores for both granted and dismissed bankruptcy filers deteriorate several years before filing. In the years prior to filing for bankruptcy, Chapter 13 filers experience a 40 to 50 point decline in credit score. Credit scores increase slightly for both dismissed and granted filers after filing, with granted filers experiencing a quicker score increase. Following our above calculations, we find that Chapter 13 protection mitigates about 50.8 percent of the potential deterioration in credit scores.

\section{F. Suggestive Evidence of Mechanisms}

In this section, we explore two potential mechanisms that might explain our findings: (1) protection from debt collectors and (2) debt forgiveness. ${ }^{16}$

We test the importance of the Chapter 13 provision that puts a hold on debt collection efforts using across-state variation in state garnishment laws. In the four states that do not allow wage garnishment - Florida, Pennsylvania, South Carolina, and Texas - creditors have fewer options to collect unpaid debts from dismissed filers. Treatment effects in states that allow wage garnishment include the effect of the hold on debt collection, debt forgiveness, and asset retention. Treatment effects in states that do not allow wage garnishment only include the effect of debt forgiveness and asset retention. If the two sets of estimates are different, this implies that the hold on debt collection is empirically important. ${ }^{17}$ Table 5 presents two-stage least squares results for filers in states that do and do not allow wage garnishment. Consistent with our hypothesis, we find large and statistically significant effects of Chapter 13 protection in states that allow wage garnishment, and small and imprecisely estimated effects in the four states that prohibit wage garnishment. However, only one of the eight differences is statistically significant due to the imprecision of the point estimates in states that do not allow wage garnishment. These results are therefore consistent with there being significant costs of not being protected from debt collectors that may help explain the deterioration of outcomes among dismissed filers, but are far from conclusive evidence.

\footnotetext{
${ }^{16}$ The retention of assets is a third potential mechanism that we are unable to fully test. One partial test of this hypothesis is to compare treatment effects for baseline homeowners to baseline renters. In Table 4, we find positive benefits of Chapter 13 protection for both homeowners and non-homeowners, but results are somewhat larger for homeowners. These results suggest that retention of important assets, such as a home, is a modest but important mechanism explaining our results. An alternative test of this mechanism is to compare treatment effects for homeowners and non-homeowners in states with and without judicial foreclosure. In states without judicial foreclosure, creditors can initiate foreclosure proceedings more easily. It is plausible that Chapter 13 protection may have a larger impact for homeowners in these states if the retention of the home is an important driver of our results. Appendix Table 5 presents these results. Consistent with the results discussed above, the point estimates suggest that the retention of assets is a somewhat important driver of our results. However, the imprecision of the estimates makes definitive conclusions difficult.

${ }^{17}$ It is plausible that the decision to file for Chapter 13 is influenced by state wage garnishment laws. If the effects of Chapter 13 protection are different for these filers, our estimates will also incorporate this heterogeneity of treatment effects. The same logic applies to our Chapter 7 exemption results in Table 6.
} 
Next, we test the importance of debt forgiveness using across-state variation in Chapter 7 homestead exemption levels. Recall that the Chapter 13 repayment plan must pay unsecured creditors at least as much as they would receive under Chapter 7. Moreover, the amount that unsecured creditors receive under Chapter 7 depends on state home exemption levels. If debt forgiveness is empirically important, the effect of Chapter 13 protection should therefore be larger in states that have high exemptions where filers are able to discharge a larger fraction of their debt. Table 6 presents two-stage least squares results for baseline homeowners and renters in states with above and below median home exemption levels. The results are broadly consistent with the idea that benefits of Chapter 13 protection are larger when more debt is forgiven. However, once again, only two of the eight differences are statistically significant due to large standard errors. The effect of Chapter 13 protection on financial strain is 0.175 standard deviations larger for homeowners in high exemption states compared to homeowners in low exemption states ( $\mathrm{p}$-value $=0.116$ ), and the effect on mortgage balance is $\$ 27,709$ larger ( $\mathrm{p}$-value $=0.008$ ). For renters, we find that the effect of Chapter 13 protection on auto balance is larger in high exemption states because states with high home exemptions also have high auto exemptions. ${ }^{18}$ Our results should therefore be interpreted as suggestive evidence that debt forgiveness plays an important role in explaining our findings.

\section{G. Additional Robustness Tests}

Appendix Table 6 explores the robustness of our main results to alternative measures of judge leniency. Column 1 replicates our preferred estimates from Table 3 using the leave-one-out measure of judge leniency as an instrument for Chapter 13 protection. Column 2 uses a leave-month-out version of judge leniency as an instrument for Chapter 13 protection that purges any remaining correlation between a filer's outcomes and our instrument introduced by the estimation of the office-by-filing-month fixed effects in our first and second stage regressions. Column 3 uses a leaveone-out measure of judge leniency calculated using decisions after only 90 days to proxy for the initial judicial decision to confirm or dismiss a filing. ${ }^{19}$ Column 4 uses a randomly selected subset of 25 percent of filers to calculate a leave-month-out measure of judge leniency that is used as an instrument in the mutually exclusive subset of filers. We also test the robustness of our results using judge fixed effects directly rather than our reduced form measure of judge leniency. Columns 5 through 7 present results that use judge fixed effects as instruments for bankruptcy protection estimated using two-stage least squares, LIML, and jackknife IV, respectively. Results across all specifications are nearly identical to our preferred specifications. None of the estimates suggest that

\footnotetext{
${ }^{18}$ The correlation between a state's homestead exemptions level and auto exemptions level is 0.43.

${ }^{19}$ We calculate judge leniency using decisions after 90 days because the bulk of dismissals occur within 90 days of filing. Under the Bankruptcy Code, the Chapter 13 trustee must hold a meeting of creditors between 21 and 50 days after the debtor files for bankruptcy. A judge is required to hold a confirmation hearing for the proposed repayment plan no later than 45 days after the meeting of the creditors. Our results are qualitatively similar using decisions after 60 and 120 days post-filing.
} 
our preferred estimates are invalid.

Appendix Table 7 examines the persistence of our findings using outcomes for an unbalanced panel of filers in the sixth through eighth post-filing years. In the sixth through eighth post-filing years, Chapter 13 protection reduces the marginal recipient's financial strain by 0.127 standard deviations, reduces the amount of debt in collections by $\$ 1,931$, increases the probability of being a homeowner by 26.0 percentage points, and increases credit score by 28.8 points. While there is no change in the probability of having an open auto loan in the first five post-filing years (see Table 3), Chapter 13 protection increases the probability of having an auto loan by 12.6 percentage points by the sixth to eighth post-filing years, suggesting that dismissed filers are more likely to lose their cars several years after filing.

\section{Reconciling Estimates with Prior Literature}

Our results from Section IV show that Chapter 13 protection has an economically and statistically significant impact on the marginal recipient's financial health. These results stand in sharp contrast to the prior literature showing few benefits of filing for bankruptcy protection using non-experimental methods (e.g. Han and Li 2007, 2011, Cohen-Cole, Duygan-Bump and Montoriol-Garriga 2013, Jagtiani and Li 2014). In this section, we explore the extent to which these contrasting results can be explained by bias in the non-experimental specifications used in this literature. ${ }^{20}$

We begin by revisiting the descriptive results comparing the means of granted and dismissed filers before and after filing. Outcomes for both dismissed and granted filers are worse than nonfilers even before filing. Moreover, the outcomes of both dismissed and granted bankruptcy filers deteriorate one to two years before filing, and remain depressed after filing. For example, consider our credit score results discussed above. Four years before filing, credit scores for both granted and dismissed filers are over 100 points lower than non-filers. In the years prior to filing for bankruptcy, both groups of filers experience a 40 to 50 point decline in credit score. Credit scores increase slightly for both dismissed and granted filers after filing, with granted filers experiencing a quicker score increase.

These descriptive results suggest that non-experimental estimates are likely to be biased downwards for at least two reasons. First, there are important differences between filers and non-filers

\footnotetext{
${ }^{20}$ There are at least two other reasons why our estimates would deviate from the prior literature. First, the prior literature has largely relied on either small samples of survey responses (e.g. Han and Li 2007, 2011), or administrative credit bureau data over a limited time span (e.g. Cohen-Cole, Duygan-Bump and Montoriol-Garriga 2013). Our analysis uses administrative credit data linked to bankruptcy filings that cover at least five post-filing years for all filers. It is possible that the benefits of bankruptcy protection are only detectable with the larger sample size and a longer time horizon afforded by our data. Consistent with this explanation, we find that our results are more modest one year after filing compared to subsequent post-filing years. Second, many analyses have considered the effects of filing for Chapter 7 and Chapter 13 bankruptcy together (e.g. Han and Li 2011, Cohen-Cole, DuyganBump and Montoriol-Garriga 2013). Dobbie and Song (forthcoming) find that the effects of Chapter 7 protection on labor supply and mortality are smaller than the effects of Chapter 13.
} 
that may not be fully accounted for by the controls that are typically available in survey data. Second, there is significant selection into filing even conditional on pre-filing characteristics. Our descriptive data suggests that bankruptcy filings are often the result of adverse shocks that have independent effects on outcomes even after filing. In this scenario, both OLS estimates with a nonfiling comparison group and within-individual estimates will be downward biased. The magnitude of the bias is likely to be decreasing in the number of available baseline controls that can account for pre-filing differences, and the number of available baseline observations before the pre-filing deterioration of outcomes. ${ }^{21}$

Table 7 presents formal OLS and within-individual estimates that test these predictions. Columns 1 and 2 of Table 7 present OLS results comparing discharged Chapter 13 filers to non-filers living in the same zip code. We exclude dismissed Chapter 13 filers from this comparison to focus on the effects of receiving Chapter 13 protection. ${ }^{22}$ Column 1 only controls for zip code-by-filing year fixed effects. Column 2 adds our standard set of baseline controls to account for observable differences between discharged filers and non-filers. Standard errors are clustered at the zip code level. We find that discharged Chapter 13 filers have lower credit scores and higher financial strain compared to non-filers. We also find that Chapter 13 filers have lower revolving, mortgage, and auto balances compared to non-filers. Collections balances, revolving utilization, and non-mortgage inquiries are higher among Chapter 13 recipients in our specification without controls, but lower when we include our baseline controls. These results are broadly consistent with those reported in Han and Li (2011), who use data from the Survey of Consumer Finances to show that bankruptcy filers have less wealth compared to non-filers.

Column 3 presents within-individual estimates comparing the pre- and post-filing outcomes of discharged Chapter 13 filers. We use three years of baseline data to estimate the individual fixed effects, and cluster standard errors at the individual level. We find that these within-individual estimates yield incorrectly signed point estimates for financial strain, mortgage balance, and credit scores. As discussed above, this finding is likely due to adverse shocks that independently affect postfiling outcomes. These results are also consistent with Cohen-Cole, Duygan-Bump, and MontoriolGarriga (2013), who find that filers have less access to credit after filing using credit bureau data. ${ }^{23}$

Columns 4 through 6 present results comparing dismissed and discharged Chapter 13 filers. This

\footnotetext{
${ }^{21}$ The pre-filing fall in outcomes is similar to the drop in earnings among participants in job training programs. See Ashenfelter (1978), Ashenfelter and Card (1985), and Heckman and Hotz (1989) for additional discussion.

${ }^{22}$ To remain consistent with the panel format of our judge sample, we create pseudo filing events for non-filers in the national sample. We randomly assign all credit users in the national sample one of four pseudo filing years between 2003 and 2006. We then exclude individuals who filed for bankruptcy in any of the years prior to this pseudo filing date. Remaining individuals comprise the non-filer comparison group.

${ }^{23}$ Specifications that use only one year of pre-filing data to estimate the individual fixed effects yield point estimates that are correctly signed for most outcomes. This surprising result is due to the individual fixed effects being measured in a year where outcomes are most depressed. As a result, mean reversion in the outcomes of granted filers generates upwards bias.
} 
approach is in the spirit of Bound's (1989) analysis of accepted and rejected Disability Insurance applicants, and more recent work estimating the effects of job loss on subsequent outcomes (Jacobson, Lalonde, and Sullivan 1993, von Wachter, Song, and Manchester 2009, Sullivan and von Wachter 2009). With the exception of Dobbie and Song (forthcoming), the previous bankruptcy literature has not used dismissed filers as a comparison group. Following our earlier results with a non-filer comparison group, column 4 presents results with zip code-by-filing year fixed effects, column 5 adds our standard set of baseline controls, and column 6 adds individual fixed effects. We cluster standard errors at the office level for columns 4 and 5, and at the individual level for column 6. In contrast to the non-experimental estimates discussed above, the non-experimental estimates with a dismissed filer comparison group are broadly consistent with our judge IV estimates. We find that Chapter 13 filers granted bankruptcy protection have lower financial strain than dismissed filers, and have less collections debt, higher mortgage balances, more credit access, and higher credit scores.

In sum, the results from Table 7 are consistent with both OLS estimates using a non-filer comparison group and within-individual estimates being biased against finding any benefits of bankruptcy protection. Using these non-experimental approaches, we find qualitatively similar results to the prior literature (Han and Li 2007, 2011, Cohen-Cole, Duygan-Bump, and Montoriol-Garriga 2013). In contrast, estimates using a dismissed filer comparison group are broadly consistent with our judge IV estimates, suggesting that selection into filing accounts for most of the bias in non-experimental specifications.

\section{Conclusion}

In this paper, we exploit the random assignment of bankruptcy filers to judges to estimate the impact of Chapter 13 bankruptcy protection on post-filing financial outcomes. We find that Chapter 13 protection reduces financial strain, increases the probability of being a homeowner, and reduces the amount of debt in collection. Chapter 13 protection also increases credit scores and credit access proxies. The effects of Chapter 13 protection are largest in states with more creditor-friendly laws and states with higher Chapter 7 exemption levels, suggesting that protection from debt collectors and debt forgiveness are key drivers of our results.

Our results compliment earlier work by Dobbie and Song (forthcoming) showing that Chapter 13 protection increases earnings and reduces mortality risk among marginal recipients. The results in this paper suggest that Chapter 13 protection also has important impacts on financial well-being and economic stability. Importantly, and contrary to much of the prior literature, we find that Chapter 13 decreases the likelihood of adverse financial events, allows debtors to retain important assets such as a home, and increases both credit access measures and credit scores. These results 
suggest that the benefits of bankruptcy protection are more broader than previously realized.

Both papers also find that the benefits of bankruptcy protection are driven by a deterioration of outcomes among dismissed filers, rather than gains among granted filers. These results provide new evidence on the mechanisms through which excessive debt and financial distress distort borrower behavior. In particular, our results suggest that both excessive debt and the debt collection process have significant long-term consequences, and that bankruptcy protection can ameliorate many of these adverse consequences.

The findings from this paper and Dobbie and Song (forthcoming) will also help inform ongoing efforts to evaluate the welfare impact of the consumer bankruptcy system. These evaluations typically use quantitative models to weigh the trade-off between the ex-post consumption smoothing benefits provided by bankruptcy protection estimated in this paper, with the ex-ante increased borrowing costs suggested by economic theory (e.g. Athreya 2002, Li and Sarte 2006, Livshits, MacGee, and Tertilt 2007, Chatterjee and Gordon 2012). An important limitation of this literature has been the lack of empirical evidence on the magnitude of the benefits provided by bankruptcy protection for the marginal recipient. Our results suggest that the ex-post benefits of consumer bankruptcy on important outcomes, such as credit access and debt repayment, are significantly larger previously assumed by this literature. Moreover, we find that consumer bankruptcy also impacts a number of outcomes previously assumed to fixed, such as asset holdings and labor supply. We therefore view the incorporation of our empirical estimates into a general equilibrium model of the credit market as an important area for future research. 


\section{References}

[1] Aizer, Anna, and Joseph Doyle, Jr. Forthcoming. "Juvenile Incarceration, Human Capital, and Future Crime: Evidence from Randomly-Assigned Judges." Quarterly Journal of Economics

[2] Armour, John, and Douglas Cumming. 2008. "Bankruptcy Law and Entrepreneurship." American Law and Economics Review, 10(2): 303-350.

[3] Ashenfelter, Orley. 1978. "Estimating the Effect of Training programs on Earnings." The Review of Economics and Statistics, 60(1): 47-57.

[4] Ashenfelter, Orley and David Card. 1985. "Using the Longitudinal Structure of Earnings to Estimate the Effect of Training Programs on Earnings." The Review of Economics and Statistics, 67(4): 648-660.

[5] Athreya, Kartik. 2002. "Welfare Implications of the Bankruptcy Reform Act of 1999." Journal of Monetary Economics, 49(8): 1567-1595.

[6] Autor, David, and Susan Houseman. 2010. "Do Temporary-Help Jobs Improve Labor Market Outcomes for Low-Skilled Workers? Evidence from "Work First." American Economic Journal: Applied Economics, 2(3): 96-128.

[7] Avery, Robert, Paul Calem, and Glenn Canner. 2003. "An Overview of Consumer Data and Credit Reporting." Federal Reserve Bulletin, 89 (February): 47-78.

[8] Bound, John. 1989. "The Health and Earnings of Rejected Disability Insurance Applicants." The American Economic Review, 79(3): 482-503.

[9] Campbell, John Y., Stefano Giglio, and Parag Pathak. 2011. "Forced Sales and House Prices." American Economic Review, 101(5): 2108-2131.

[10] Chang, Tom, and Antoinette Schoar. 2008. "Judge Specific Differences in Chapter 11 and Firm Outcomes." Unpublished Working Paper.

[11] Chatterjee, Satyajit, and Grey Gordon. 2012. "Dealing with Consumer Default: Bankruptcy vs Garnishment." Journal of Monetary Economics, 59(15): S1-S16.

[12] Cohen-Cole, Ethan, Burcu Duygan-Bump, and Judit Montoriol-Garriga. 2013. "Who Gets Credit After Bankruptcy and Why? An Information Channel." Journal of Banking and Finance, 37(12): 5101-5117.

[13] Domowitz, Ian, and Robert Sartain. 1999. "Determinants of the Consumer Bankruptcy Decision." The Journal of Finance, 54(1): 403-420.

[14] Dobbie, Will, and Paul Goldsmith-Pinkham. 2014. "Debt Protections and the Great Recession." Unpublished Working Paper.

[15] Dobbie, Will, and Jae Song. Forthcoming. "Debt Relief and Debtor Outcomes: Measuring the Effects of Consumer Bankruptcy Protection." American Economic Review.

[16] Doyle, Joseph. 2007. "Child Protection and Child Outcomes: Measuring the Effects of Foster Care." American Economic Review, 97(5): 1583-1610.

[17] Doyle, Joseph. 2008. "Child Protection and Adult Crime: Using Investigator Assignment to Estimate Causal Effects of Foster Care." Journal of Political Economy, 116(4): 746-770.

[18] Eggertson, Gauti B., and Paul Krugman. 2012. "Debt, Deleveraging, and the Liquidity Trap: A Fisher-Minsky-Koo Approach." The Quarterly Journal of Economics, 127(3): 1469-1513.

[19] Fan, Wei, and Michelle White. 2003. "Personal Bankruptcy and the Level of Entrepreneurial Activity." Journal of Law and Economics, 46(2): 543-567. 
[20] Farhi, Emmanuel, and Ivan Werning. 2013. "A Theory of Macroprudential Policies in the Presence of Nominal Rigidities." NBER Working Paper No. 19313.

[21] Fay, Scott, Erik Hurst, and Michelle White. 2002. "The Household Bankruptcy Decision." American Economic Review, 92(3): 706-718.

[22] Federal Reserve Bank of New York. 2014. Quarterly Report on Household Debt and Credit.

[23] Finkelstein, Amy, Sarah Taubman, Bill Wright, Mira Bernstein, Jonathan Gruber, Joseph P. Newhouse, Heidi Allen, Katherine Baicker, and Oregon Health Study Group. 2012. "The Oregon Health Insurance Experiment: Evidence from the First Year." The Quarterly Journal of Economics, 127(3): 1057-1106.

[24] French, Eric, and Jae Song. 2014. "The Effect of Disability Insurance Receipt on Labor Supply." American Economic Journal: Economic Policy, 6(2): 291-337.

[25] Fryer, Roland, and L Katz. 2013. "Achieving Escape Velocity: Neighborhood and School Interventions to Reduce Persistent Inequality." American Economic Review (Papers and Proceedings), 103(3): 232-237.

[26] Guerrieri, Veronica, and Guido Lorenzoni. 2011. "Credit Crises, Precautionary Savings, and the Liquidity Trap." NBER Working Paper No. 17583.

[27] Han, Song, and Geng Li. 2007. "Fresh Start or Head Start? The Effect of Filing for Personal Bankruptcy on Labor Supply." Journal of Financial Services Research, 31(2): 123-152.

[28] Han, Song, and Geng Li. 2011. "Household Borrowing after Personal Bankruptcy." Journal of Money, Credit and Banking, 43(2-3): 491-517.

[29] Han, Song, Benjamin J. Keys, and Geng Li. 2013. "Unsecured Credit Supply over the Credit Cycle: Evidence from Credit Card Mailings." Unpublished Working Paper.

[30] Heckman, James, and V. Joseph Hotz. 1989. "Choosing Among Alternative Nonexperimental Methods for Estimating the Impact of Social Programs: The Case of Manpower Training." Journal of the American Statistical Association, 84(408): 862-874.

[31] Himmelstein, David, Deborah Thorne, Elizabeth Warren, and Steffie Woolhandler. 2009. "Medical Bankruptcy in the United States, 2007: Results of a National Study." American Journal of Medicine, 122 (8): 741-746.

[32] Hynes, Richard. 2004. "Why (Consumer) Bankruptcy?" Alabama Law Review, 56(1): 121-179.

[33] Hynes, Richard M., Amanda E. Dawsey, and Lawrence M. Ausubel. 2013. "Non-Judicial Debt Collection and the Consumer's Choice Among Repayment, Bankruptcy and Informal Bankruptcy." American Bankruptcy Law Journal, 87(1): 1-26.

[34] Jacobson, Louis, Robert LaLonde and Daniel Sullivan. 1993. "Earnings Losses of Displaced Workers." American Economic Review, 83(4): 685-709.

[35] Jagtiani, Julapa and Wenli Li. Forthcoming. "Credit Access After Consumer Bankruptcy Filing: New Evidence." American Bankruptcy Law Journal.

[36] Kling, Jeffrey. 2006. "Incarceration Length, Employment, and Earnings." American Economic Review, 96(3): 863-876.

[37] Krugman, Paul. 1988. "Financing vs. Forgiving a Debt Overhang." NBER Working Paper No. 2486.

[38] Li, Wenli and Pierre-Daniel Sarte. 2006. "U.S. Consumer Bankruptcy Choice: The Importance of General Equilibrium Effects." Journal of Monetary Economics, 53(3): 613-631. 
[39] Livshits, Igor, James MacGee, and Michele Tertilt. 2007. "Consumer Bankruptcy: A Fresh Start." American Economic Review, 97(1): 402-418.

[40] Maestas, Nicole, Kathleen Mullen, and Alexander Strand. 2013. "Does Disability Insurance Receipt Discourage Work? Using Examiner Assignment to Estimate Causal Effects of SSDI Receipt." American Economic Review, 103(5): 1797-1829.

[41] Mahoney, Neale. Forthcoming. "Bankruptcy as Implicit Health Insurance." American Economic Review.

[42] Melzer, Brian. 2012. "Mortgage Debt Overhang: Reduced Investment by Homeowners with Negative Equity." Unpublished Working Paper.

[43] Mian, Atif, Amir Sufi, and Francesco Trebbi. 2013. "The Political Economy of the Subprime Mortgage Credit Expansion." Quarterly Journal of Political Science, 8(4): 373-408.

[44] Mian, Atif, Kamalesh Rao, and Amir Sufi. 2013. "Household Balance Sheets, Consumption, and the Economic Slump." The Quarterly Journal of Economics, 128(4): 1687-1726.

[45] Mian, Atif, and Amir Sufi. Forthcoming. "What Explains the 2007-2009 Drop in Employment?" Econometrica.

[46] Midrigan, Virgiliu, and Thomas Philippon. 2011. "Household Leverage and the Recession." NBER Working Paper No. 16965.

[47] Myers, Stewart. 1977. "Determinants of Corporate Borrowing." Journal of Financial Economics, 5(1977): 147-175.

[48] Norberg, Scott, and Nadia Compo. 2007. "Report on an Empirical Study of District Variations, and the Roles of Judges, Trustees and Debtor's Attorneys in Chapter 13 Bankruptcy Cases." The American Bankruptcy Law Journal, 81(4): 431-493.

[49] Porter, Katherine. 2011. "The Pretend Solution: An Empirical Study of Bankruptcy Outcomes." Texas Law Review, 90(103): 104-162.

[50] Sullivan, Daniel, and Till von Wachter. 2009. "Job Displacement and Mortality: An Analysis Using Administrative Data." Quarterly Journal of Economics, 124(3): 1265-1306.

[51] Sullivan, Teresa, Elizabeth Warren, and Jay Westbrook. 2000. The Fragile Middle Class: Americans in Debt. New Haven, CT: Yale University Press.

[52] von Wachter, Till, Jae Song, and Joyce Manchester. 2009. "Long-Term Earnings Losses due to Mass-Layoffs During the 1982 Recession: An Analysis Using Longitudinal Administrative Data from 1974 to 2004." Unpublished Working Paper.

[53] Warren, Elizabeth, Teresa Sullivan, and Melissa Jacoby. 2000. "Medical Problems and Bankruptcy Filings." Norton Bankruptcy Law Advisor, May 2000.

[54] White, Michelle, and Ning Zhu. 2010. "Saving Your Home in Chapter 13 Bankruptcy." Journal of Legal Studies, 39(1): 33-61.

[55] White, Michelle. 2011. "Corporate and Personal Bankruptcy Law." Annual Review of Law and Social Science, 7: 139-164.

[56] Zywicki, Todd J. 2005. "An Economic Analysis of the Consumer Bankruptcy Crisis." Northwestern University Law Review, 99(4): 1463-1541. 
Table 1

Descriptive Statistics and Randomization Balance

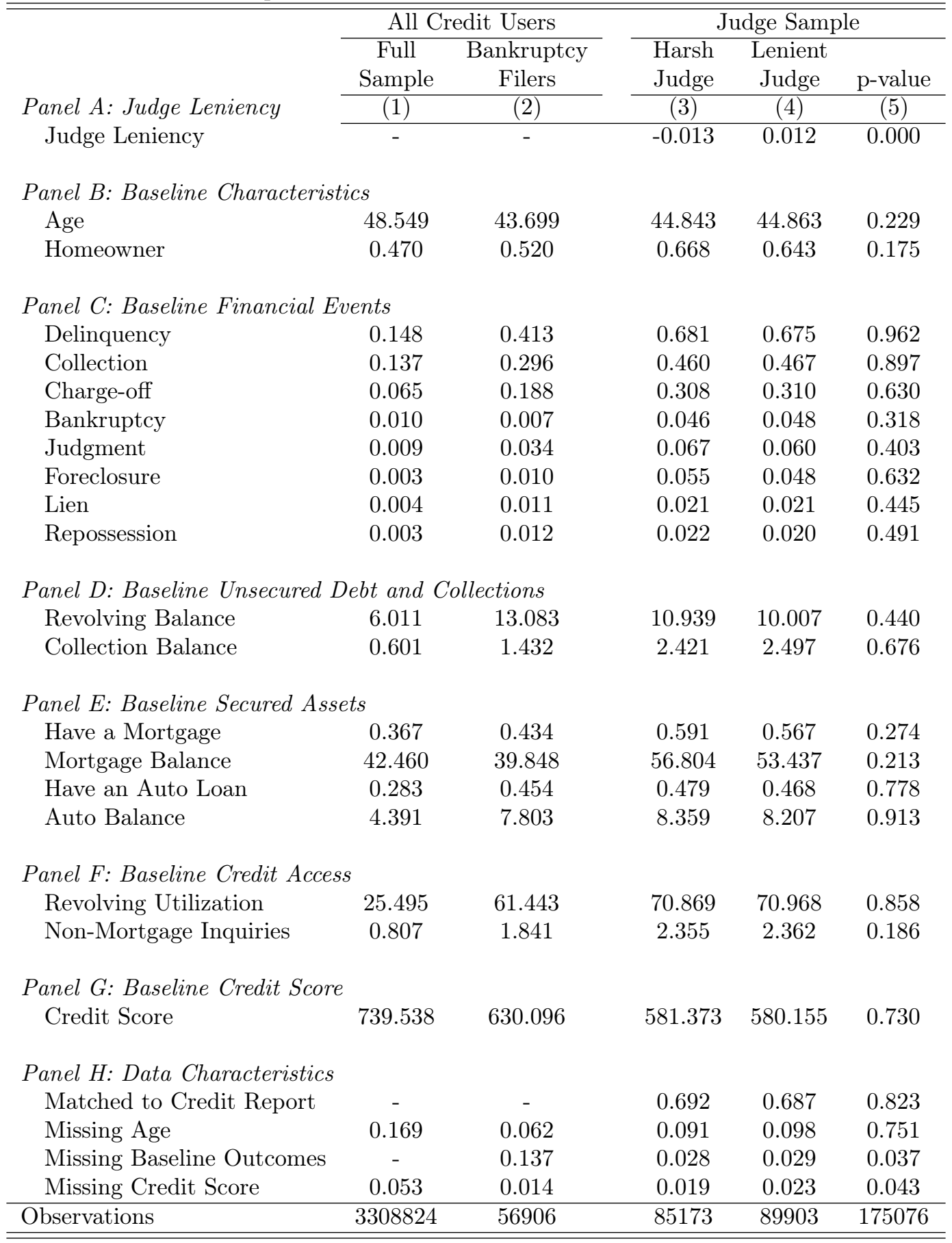

Notes: This table reports summary statistics. The all credit user sample consists of a two percent random sample of credit users in the United States from 2002-2005. Bankruptcy filers consist of individuals who filed for any bankruptcy chapter from 2002-2006. The judge sample consists of Chapter 13 bankruptcy filers originating from offices that randomly assigns filers to judges between 2002-2005 that are linked to credit report data in the year of filing. Column 5 reports p-values calculated from separate regression models of each baseline characteristic on an indicator for being assigned to a judge with above median leniency. Column 5 also controls for office-by-filing-month fixed effects and clusters standard errors at the office level. See the data appendix for details on the data and variable construction. 
Table 2

Judge Leniency and Chapter 13 Protection

\begin{tabular}{|c|c|c|c|c|c|c|}
\hline & $\overline{(1)}$ & 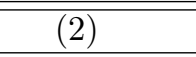 & 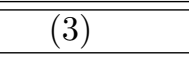 & $\overline{(4)}$ & 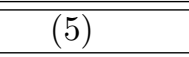 & 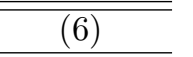 \\
\hline Judge Leniency & $\begin{array}{c}0.88872^{\text {** }} \\
(0.04873)\end{array}$ & $\begin{array}{c}0.83789^{* * *} \\
(0.05299)\end{array}$ & $\begin{array}{c}0.84220^{* * *} \\
(0.04777)\end{array}$ & $\begin{array}{c}0.85585^{\text {*** }} \\
(0.05243)\end{array}$ & $\begin{array}{c}0.85780^{* * *} \\
(0.04588)\end{array}$ & $\begin{array}{c}0.81092^{* * *} \\
(0.05186)\end{array}$ \\
\hline Age at Filing & & $\begin{array}{l}0.00305^{* * *} \\
(0.00016)\end{array}$ & $\begin{array}{l}0.00235^{* * *} \\
(0.00018)\end{array}$ & $\begin{array}{l}0.00424^{* * *} \\
(0.00017)\end{array}$ & $\begin{array}{l}0.00310^{* * *} \\
(0.00017)\end{array}$ & $\begin{array}{c}0.00072^{* * *} \\
(0.00018)\end{array}$ \\
\hline Homeowner & & $\begin{array}{l}0.03749^{* * *} \\
(0.01047)\end{array}$ & $\begin{array}{r}-0.01142 \\
(0.01305)\end{array}$ & $\begin{array}{l}0.02574^{* * *} \\
(0.00512)\end{array}$ & $\begin{array}{c}0.00205 \\
(0.01222)\end{array}$ & $\begin{array}{r}-0.00827 \\
(0.00536)\end{array}$ \\
\hline Delinquency & & $\begin{array}{c}-0.06518^{* * * *} \\
(0.00908)\end{array}$ & & & & $\begin{array}{l}0.03066^{* * *} \\
(0.00402)\end{array}$ \\
\hline Collection & & $\begin{array}{c}-0.12082^{* * * *} \\
(0.00765)\end{array}$ & & & & $\begin{array}{c}-0.04848^{* * *} \\
(0.00428)\end{array}$ \\
\hline Charge-off & & $\begin{array}{c}0.00413 \\
(0.00320)\end{array}$ & & & & $\begin{array}{c}0.00117 \\
(0.00267)\end{array}$ \\
\hline Bankruptcy & & $\begin{array}{c}-0.13191^{* * *} \\
(0.01038)\end{array}$ & & & & $\begin{array}{c}-0.08388^{* * *} \\
(0.00809)\end{array}$ \\
\hline Judgment & & $\begin{array}{c}-0.07933^{* * * *} \\
(0.01277)\end{array}$ & & & & $\begin{array}{c}-0.04120^{* * *} \\
(0.01031)\end{array}$ \\
\hline Foreclosure & & $\begin{array}{c}-0.17495^{* * * *} \\
(0.01508)\end{array}$ & & & & $\begin{array}{c}-0.12185^{* * *} \\
(0.01319)\end{array}$ \\
\hline Lien & & $\begin{array}{c}-0.10001^{* * *} \\
(0.00847)\end{array}$ & & & & $\begin{array}{c}-0.06406^{* * *} \\
(0.00842)\end{array}$ \\
\hline Repossession & & $\begin{array}{c}-0.02670^{* * *} \\
(0.00855)\end{array}$ & & & & $\begin{array}{c}0.00054 \\
(0.00804)\end{array}$ \\
\hline Revolving Balance & & & $\begin{array}{l}0.00575^{* * *} \\
(0.00025)\end{array}$ & & & $\begin{array}{l}0.00487^{* * *} \\
(0.00021)\end{array}$ \\
\hline Collection Balance & & & $\begin{array}{c}-0.00617^{* * *} \\
(0.00051)\end{array}$ & & & $\begin{array}{c}-0.00206^{* * *} \\
(0.00038)\end{array}$ \\
\hline Have a Mortgage & & & & $\begin{array}{c}0.00883 \\
(0.01359)\end{array}$ & & $\begin{array}{l}0.04324^{* * *} \\
(0.00972)\end{array}$ \\
\hline Mortgage Balance & & & & $\begin{array}{c}-0.00028^{* * *} \\
(0.00007)\end{array}$ & & $\begin{array}{c}-0.00039^{* * *} \\
(0.00005)\end{array}$ \\
\hline Have an Auto Loan & & & & $\begin{array}{l}0.10670^{* * *} \\
(0.00488)\end{array}$ & & $\begin{array}{l}0.06466^{* * *} \\
(0.00463)\end{array}$ \\
\hline Auto Balance & & & & $\begin{array}{c}-0.00065^{* * *} \\
(0.00024)\end{array}$ & & $\begin{array}{c}-0.00068^{* * *} \\
(0.00022)\end{array}$ \\
\hline Revolving Utilization & & & & & $\begin{array}{c}-0.00004 \\
(0.00003)\end{array}$ & $\begin{array}{l}0.00009^{* * *} \\
(0.00002)\end{array}$ \\
\hline Non-Mortgage Inquiries & & & & & $\begin{array}{c}-0.01126^{\text {*** }} \\
(0.00081)\end{array}$ & $\begin{array}{c}* 0.00861^{* * *} \\
(0.00069)\end{array}$ \\
\hline Credit Score & & & & & $\begin{array}{l}0.00075^{\text {*** }} \\
(0.00008)\end{array}$ & $\begin{array}{c}0.00142^{* * *} \\
(0.00005)\end{array}$ \\
\hline Observations & 175076 & 175076 & 175076 & 175076 & 175076 & 175076 \\
\hline
\end{tabular}

Notes: This table reports first stage results. The sample consists of Chapter 13 bankruptcy filers originating from offices that randomly assigns filers to judges between 2002-2005 that are linked to credit report data in the year of filing. Judge leniency is the leave-one-out mean rate of granting Chapter 13 bankruptcy protection for the assigned judge minus the leave-one-out mean rate of granting bankruptcy protection for the office. All characteristics are measured one year prior to the bankruptcy filing. All regressions control for office-by-filing-month fixed effects and cluster standard errors at the office level. See the data appendix for details on the data and variable construction. $*^{* *}=$ significant at 1 percent level, ${ }^{* *}=$ significant at 5 percent level, ${ }^{*}=$ significant at 10 percent level. 
Table 3

Chapter 13 Protection and Financial Well-Being

\begin{tabular}{|c|c|c|c|}
\hline \multirow{3}{*}{$\begin{array}{l}\text { Panel A: Adverse Financial Events } \\
\text { Financial Strain Index }\end{array}$} & \multirow{2}{*}{$\begin{array}{c}\text { Dismissed } \\
\text { Mean }\end{array}$} & \multicolumn{2}{|c|}{ 2SLS Results } \\
\hline & & $(2)$ & $(3)$ \\
\hline & $\begin{array}{l}-0.068 \\
(0.575)\end{array}$ & $\begin{array}{l}-0.369^{* * *} \\
(0.070)\end{array}$ & $\begin{array}{l}-0.316^{* * *} \\
(0.071)\end{array}$ \\
\hline Delinquency & $\begin{array}{c}0.596 \\
(0.292)\end{array}$ & $\begin{array}{c}0.019 \\
(0.017)\end{array}$ & $\begin{array}{c}0.013 \\
(0.018)\end{array}$ \\
\hline Collection & $\begin{array}{c}0.584 \\
(0.305)\end{array}$ & $\begin{array}{l}-0.201^{* * *} \\
(0.053)\end{array}$ & $\begin{array}{c}-0.149^{* *} \\
(0.061)\end{array}$ \\
\hline Charge-off ${ }^{\dagger}$ & $\begin{array}{c}0.216 \\
(0.227)\end{array}$ & $\begin{array}{l}-0.065^{* * *} \\
(0.017)\end{array}$ & $\begin{array}{l}-0.067^{* * *} \\
(0.020)\end{array}$ \\
\hline New Bankruptcy ${ }^{\dagger}$ & $\begin{array}{c}0.109 \\
(0.167)\end{array}$ & $\begin{array}{l}-0.064^{* * *} \\
(0.023)\end{array}$ & $\begin{array}{l}-0.065^{* * *} \\
(0.025)\end{array}$ \\
\hline Foreclosure & $\begin{array}{c}0.070 \\
(0.139)\end{array}$ & $\begin{array}{l}-0.030^{* * *} \\
(0.009)\end{array}$ & $\begin{array}{r}-0.016^{*} \\
(0.008)\end{array}$ \\
\hline Judgment & $\begin{array}{l}0.066 \\
(0.128)\end{array}$ & $\begin{array}{c}-0.039^{* *} \\
(0.016)\end{array}$ & $\begin{array}{r}-0.031^{*} \\
(0.016)\end{array}$ \\
\hline Lien & $\begin{array}{c}0.034 \\
(0.099)\end{array}$ & $\begin{array}{l}-0.034^{* * *} \\
(0.012)\end{array}$ & $\begin{array}{c}-0.034^{* *} \\
(0.013)\end{array}$ \\
\hline Repossession & $\begin{array}{l}0.019 \\
(0.064)\end{array}$ & $\begin{array}{l}-0.015^{* * *} \\
(0.006)\end{array}$ & $\begin{array}{c}-0.016^{* *} \\
(0.006)\end{array}$ \\
\hline \multicolumn{4}{|c|}{ Panel B: Unsecured Debt and Collections } \\
\hline Revolving Balance & $\begin{array}{c}2.563 \\
(6.065)\end{array}$ & $\begin{array}{c}0.199 \\
(0.720)\end{array}$ & $\begin{array}{r}-0.920 \\
(0.745)\end{array}$ \\
\hline Collection Balance & $\begin{array}{c}4.217 \\
(5.898)\end{array}$ & $\begin{array}{l}-1.842^{* * *} \\
(0.449)\end{array}$ & $\begin{array}{l}-1.315^{* * *} \\
(0.432)\end{array}$ \\
\hline \multicolumn{4}{|l|}{ Panel C: Secured Assets } \\
\hline Have a Mortgage & $\begin{array}{c}0.363 \\
(0.369)\end{array}$ & $\begin{array}{l}0.110^{* *} \\
(0.045)\end{array}$ & $\begin{array}{l}0.132^{* * *} \\
(0.021)\end{array}$ \\
\hline Mortgage Balance & $\begin{array}{c}26.833 \\
(41.359)\end{array}$ & $\begin{array}{l}12.196^{* * *} \\
(4.132)\end{array}$ & $\begin{array}{l}14.267^{* * *} \\
(4.955)\end{array}$ \\
\hline Have an Auto Loan & $\begin{array}{c}0.178 \\
(0.263)\end{array}$ & $\begin{array}{c}0.046^{*} \\
(0.028)\end{array}$ & $\begin{array}{c}0.020 \\
(0.032)\end{array}$ \\
\hline Auto Balance & $\begin{array}{c}4.067 \\
(5.797)\end{array}$ & $\begin{array}{c}-0.500 \\
(0.500)\end{array}$ & $\begin{array}{c}-0.904 \\
(0.581)\end{array}$ \\
\hline \multicolumn{4}{|l|}{ Panel D: Credit Access } \\
\hline Revolving Utilization & $\begin{array}{c}46.729 \\
(46.437)\end{array}$ & $\begin{array}{c}-15.132^{* * *} \\
(3.884)\end{array}$ & $\begin{array}{c}-16.148^{* * *} \\
(3.282)\end{array}$ \\
\hline Non-Mortgage Inquiries & $\begin{array}{c}1.584 \\
(1.487)\end{array}$ & $\begin{array}{c}-0.410^{* * *} \\
(0.121)\end{array}$ & $\begin{array}{c}-0.293^{* *} \\
(0.118)\end{array}$ \\
\hline \multicolumn{4}{|l|}{ Panel E: Credit Score } \\
\hline Credit Score & $\begin{array}{l}565.433 \\
(44.543)\end{array}$ & $\begin{array}{l}28.511^{* * *} \\
(4.234)\end{array}$ & $\begin{array}{l}14.981^{* * *} \\
(3.270)\end{array}$ \\
\hline Controls & - & No & Yes \\
\hline Observations & 97006 & 175076 & 175076 \\
\hline
\end{tabular}


Notes: This table reports two-stage least squares results of the impact of Chapter 13 bankruptcy protection on post-filing outcomes. The sample consists of Chapter 13 bankruptcy filers originating from offices that randomly assigns filers to judges between 2002-2005 that are linked to credit report data in the year of filing. All outcomes are annual averages for the year of filing to fifth year post-filing, with the exceptions of outcomes with a $\dagger$ where outcomes are averaged over the first full year after filing to the fifth year post-filing to remove the mechanical effect of the bankruptcy filing. Column 1 reports the post-filing mean and standard deviation for dismissed filers. Columns 2-3 instrument for Chapter 13 protection using the leave-one-out mean rate of granting Chapter 13 bankruptcy protection for the assigned judge minus the leave-one-out mean rate of granting bankruptcy protection for the office. All regressions control for office-by-filing-month fixed effects and cluster standard errors at the office level. Column 3 adds controls for baseline age bins, homeownership, credit score, financial strain index, revolving balance, collection balance, mortgage balance, auto balance, indicators for mortgage and auto loans, revolving utilization, and nonmortgage inquiries as controls. The financial strain index contains the non-cumulative probabilities of the following eight components: delinquency, collection, charge-off, bankruptcy, foreclosure, judgment, lien and repossession. For each year post-filing, each component is standardized using the mean and standard deviation for the dismissed filer group in the baseline year. We sum across the eight components to create an index, restandardizing using the mean and standard deviation of the dismissed filer group in the baseline period. The index is then averaged over the five years post-filing. See the data appendix for details on the data and variable construction. $* * *=$ significant at 1 percent level, ${ }^{* *}=$ significant at 5 percent level, ${ }^{*}=$ significant at 10 percent level. 


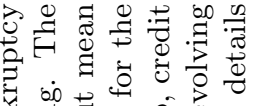

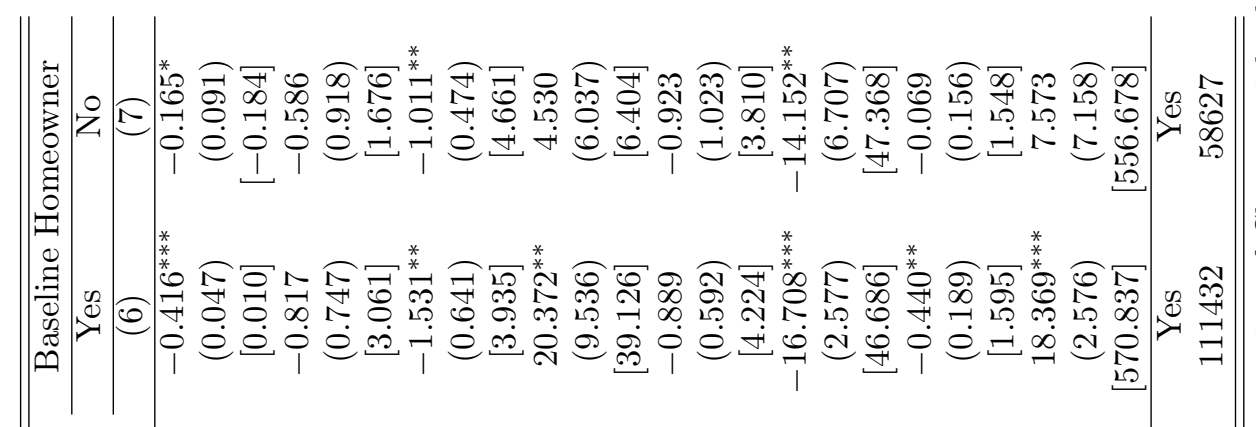

శై

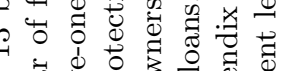

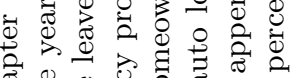

बٓ

.

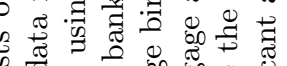

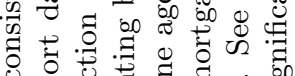

Oे

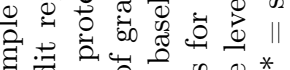

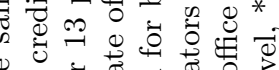

苟

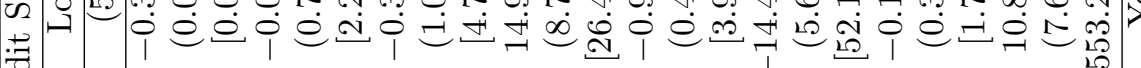

要

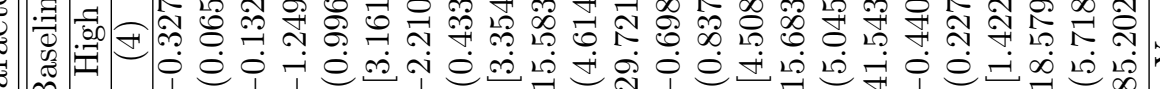

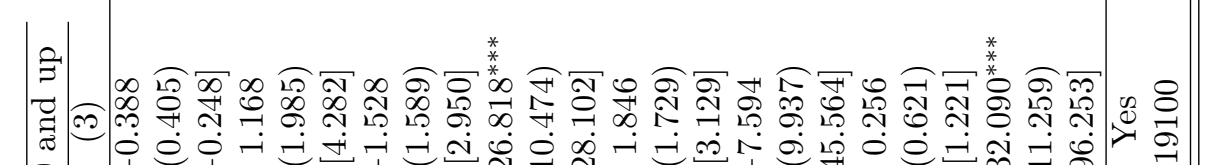

济

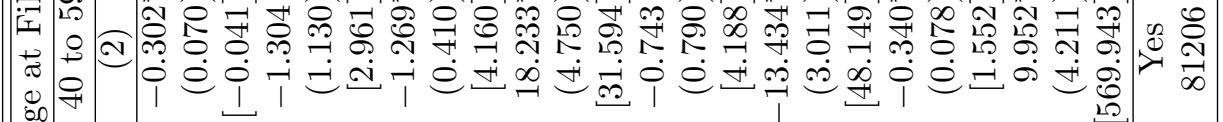

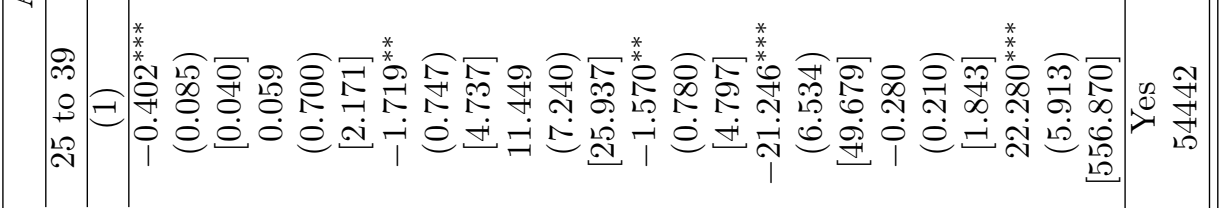

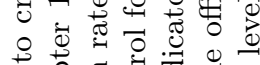

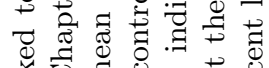

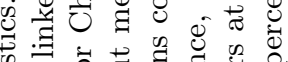

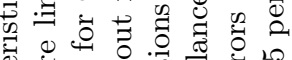
స

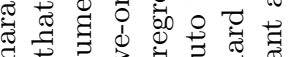
L

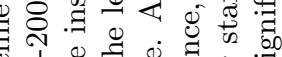

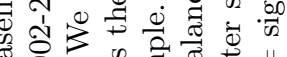
。

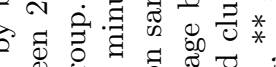

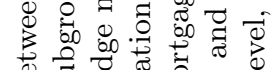

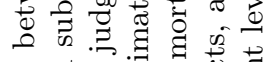

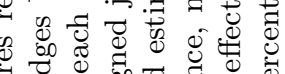
. 0 .

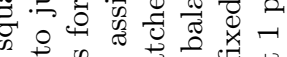
पू山

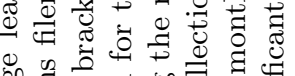
. के चु

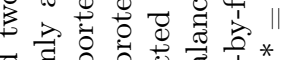

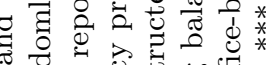

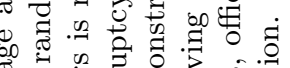
का की

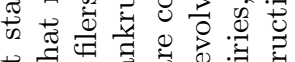

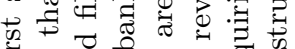

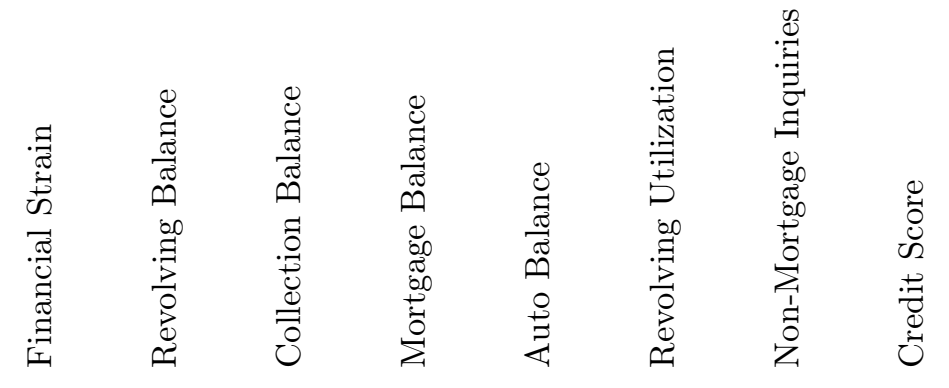
के

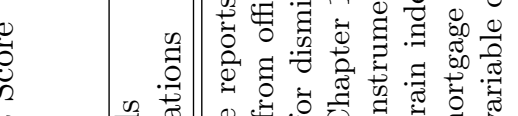

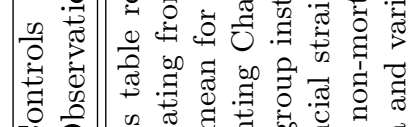

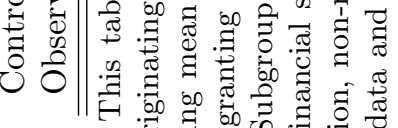

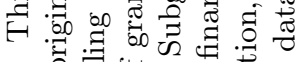
ชิ

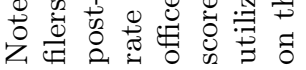


Table 5

Chapter 13 Results by State Wage Garnishment Laws

\begin{tabular}{|c|c|c|c|}
\hline & \multicolumn{3}{|c|}{ Garnishment Allowed } \\
\hline & Yes & No & p-value \\
\hline \multirow{4}{*}{ Financial Strain } & (1) & $(2)$ & $(3)$ \\
\hline & $-0.319^{* * *}$ & -0.132 & 0.449 \\
\hline & $(0.070)$ & $(0.242)$ & \\
\hline & {$[-0.058]$} & {$[-0.167]$} & \\
\hline \multirow[t]{3}{*}{ Revolving Balance } & -1.061 & 6.606 & 0.132 \\
\hline & $(0.654)$ & $(5.119)$ & \\
\hline & {$[2.477]$} & {$[3.407]$} & \\
\hline \multirow[t]{3}{*}{ Collection Balance } & $-1.285^{* * *}$ & -2.888 & 0.407 \\
\hline & $(0.441)$ & $(1.913)$ & \\
\hline & [4.190] & [4.482] & \\
\hline \multirow[t]{3}{*}{ Mortgage Balance } & $13.985^{* * *}$ & 29.399 & 0.606 \\
\hline & $(5.190)$ & $(29.864)$ & \\
\hline & {$[26.517]$} & {$[29.940]$} & \\
\hline \multirow[t]{3}{*}{ Auto Balance } & $-1.017^{*}$ & 5.158 & 0.245 \\
\hline & $(0.532)$ & $(5.366)$ & \\
\hline & {$[4.051]$} & {$[4.223]$} & \\
\hline \multirow[t]{3}{*}{ Revolving Utilization } & $-16.619^{* * *}$ & 9.060 & 0.349 \\
\hline & $(3.477)$ & $(27.639)$ & \\
\hline & {$[46.375]$} & {$[50.211]$} & \\
\hline \multirow[t]{3}{*}{ Non-Mortgage Inquiries } & $-0.319^{* * *}$ & 1.086 & 0.084 \\
\hline & $(0.120)$ & $(0.818)$ & \\
\hline & {$[1.584]$} & {$[1.584]$} & \\
\hline \multirow[t]{3}{*}{ Credit Score } & $15.243^{* * *}$ & 2.614 & 0.643 \\
\hline & $(3.180)$ & $(27.332)$ & \\
\hline & {$[564.281]$} & {$[576.741]$} & \\
\hline Controls & Yes & Yes & - \\
\hline Observations & 154611 & 20465 & - \\
\hline
\end{tabular}

Notes: This table reports two-stage least squares results of the impact of Chapter 13 bankruptcy protection for states that do and do not allow wage garnishment. The sample consists of Chapter 13 bankruptcy filers originating from offices that randomly assigns filers to judges between 2002-2005 that are linked to credit report data in the year of filing. The post-filing mean for dismissed filers is reported in brackets for each subgroup. We instrument for Chapter 13 protection using the leave-one-out mean rate of granting Chapter 13 bankruptcy protection for the assigned judge minus the leave-one-out mean rate of granting bankruptcy protection for the office. Subgroup instruments are constructed using the matched estimation sample. All regressions control for baseline age bins, homeownership, credit score, financial strain index, revolving balance, collection balance, mortgage balance, auto balance, indicators for mortgage and auto loans, revolving utilization, non-mortgage inquiries, office-by-filing-month fixed effects, and cluster standard errors at the office level. See the data appendix for details on the data and variable construction. $* * *=$ significant at 1 percent level, ${ }^{* *}=$ significant at 5 percent level, ${ }^{*}=$ significant at 10 percent level. 
Table 6

Chapter 13 Results by State Homestead Exemption Laws

\begin{tabular}{|c|c|c|c|c|c|c|}
\hline & \multicolumn{3}{|c|}{ Homeowners } & \multicolumn{3}{|c|}{ Renters } \\
\hline & High & Low & & High & Low & \\
\hline & Home Ex. & Home Ex. & $\mathrm{p}$-value & Home Ex. & Home Ex. & p-value \\
\hline \multirow{4}{*}{ Financial Strain } & (1) & $(2)$ & $(3)$ & (4) & (5) & $(6)$ \\
\hline & $-0.454^{* * *}$ & $-0.279^{* *}$ & 0.116 & $-0.180^{* *}$ & -0.159 & 0.912 \\
\hline & $(0.025)$ & $(0.114)$ & & $(0.090)$ & $(0.182)$ & \\
\hline & {$[0.032]$} & {$[-0.022]$} & & {$[-0.141]$} & {$[-0.214]$} & \\
\hline \multirow[t]{3}{*}{ Revolving Balance } & $-1.149^{* *}$ & 0.452 & 0.373 & -0.880 & -0.101 & 0.592 \\
\hline & $(0.538)$ & $(1.782)$ & & $(1.066)$ & $(1.105)$ & \\
\hline & {$[3.333]$} & {$[2.677]$} & & {$[2.010]$} & {$[1.435]$} & \\
\hline \multirow[t]{3}{*}{ Collection Balance } & $-1.670^{* * *}$ & -0.930 & 0.692 & $-1.019^{*}$ & -1.135 & 0.897 \\
\hline & $(0.602)$ & $(1.898)$ & & $(0.616)$ & $(0.793)$ & \\
\hline & {$[4.089]$} & {$[3.718]$} & & [4.699] & {$[4.634]$} & \\
\hline \multirow[t]{3}{*}{ Mortgage Balance } & $26.390^{* * *}$ & -1.319 & 0.008 & 5.566 & 7.000 & 0.853 \\
\hline & $(7.832)$ & $(7.902)$ & & $(6.412)$ & $(5.018)$ & \\
\hline & [42.984] & [33.692] & & {$[8.444]$} & {$[4.934]$} & \\
\hline \multirow[t]{3}{*}{ Auto Balance } & -0.916 & -0.594 & 0.755 & $-1.548^{* *}$ & 0.697 & 0.046 \\
\hline & $(0.708)$ & $(0.797)$ & & $(0.736)$ & $(0.993)$ & \\
\hline & {$[4.327]$} & {$[4.080]$} & & {$[4.449]$} & {$[3.350]$} & \\
\hline \multirow{3}{*}{ Revolving Utilization } & $-17.234^{* * *}$ & $-16.214^{*}$ & 0.910 & $-9.741^{*}$ & $-26.188^{* * *}$ & 0.100 \\
\hline & $(1.712)$ & $(9.174)$ & & $(5.558)$ & $(9.145)$ & \\
\hline & [46.774] & [46.561] & & [47.841] & [47.027] & \\
\hline \multirow[t]{3}{*}{ Non-Mortgage Inquiries } & $-0.501^{* *}$ & -0.194 & 0.435 & -0.169 & 0.142 & 0.215 \\
\hline & $(0.244)$ & $(0.328)$ & & $(0.108)$ & $(0.267)$ & \\
\hline & [1.637] & {$[1.537]$} & & {$[1.596]$} & {$[1.514]$} & \\
\hline \multirow[t]{3}{*}{ Credit Score } & $18.776^{* * *}$ & $16.311^{* * *}$ & 0.676 & $9.496^{*}$ & 2.743 & 0.650 \\
\hline & $(2.658)$ & $(5.572)$ & & $(5.056)$ & $(15.766)$ & \\
\hline & [572.428] & [568.595] & & [561.523] & [553.179] & \\
\hline Controls & Yes & Yes & - & Yes & Yes & - \\
\hline Observations & 61334 & 50098 & - & 25900 & 32727 & - \\
\hline
\end{tabular}

Notes: This table reports two-stage least squares results of the impact of Chapter 13 bankruptcy protection for states with above median and below median homestead exemption amounts, separately by homeownership status. The sample consists of Chapter 13 bankruptcy filers originating from offices that randomly assigns filers to judges between 2002-2005 that are linked to credit report data in the year of filing. The post-filing mean for dismissed filers is reported in brackets for each subgroup. We instrument for Chapter 13 protection using the leave-one-out mean rate of granting Chapter 13 bankruptcy protection for the assigned judge minus the leave-one-out mean rate of granting bankruptcy protection for the office. Subgroup instruments are constructed using the matched estimation sample. All regressions control for baseline age bins, homeownership, credit score, financial strain index, revolving balance, collection balance, mortgage balance, auto balance, indicators for mortgage and auto loans, revolving utilization, non-mortgage inquiries, office-by-filing-month fixed effects, and cluster standard errors at the office level. See the data appendix for details on the data and variable construction. $* * *=$ significant at 1 percent level, $* *=$ significant at 5 percent level, ${ }^{*}=$ significant at 10 percent level. 


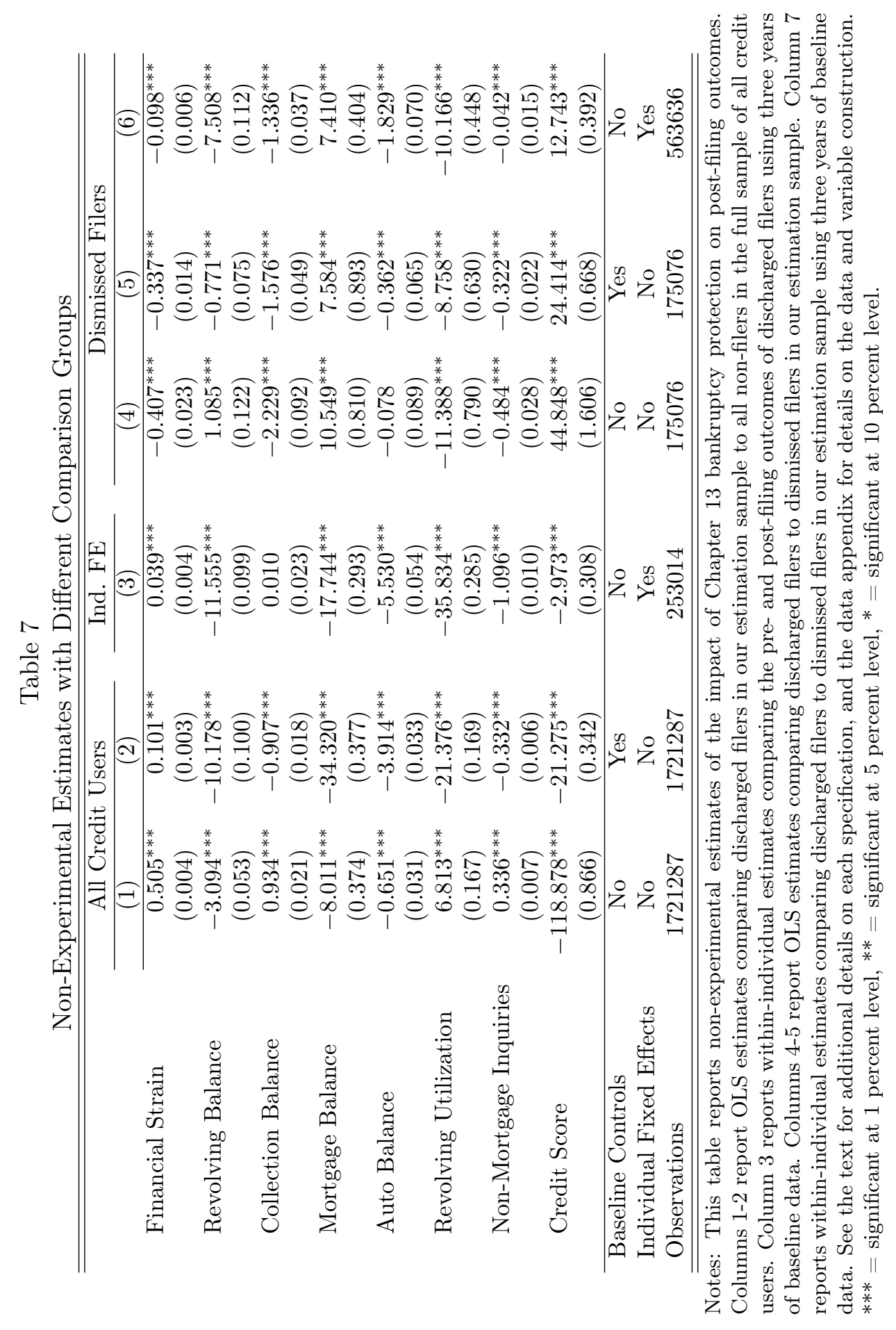


Appendix Table 1

Bankruptcy Offices in Chapter 13 IV Sample

\begin{tabular}{|c|c|c|c|c|c|}
\hline Court & Office & Years & Judges & Discharge & $\sigma_{Z}$ \\
\hline Northern District of Alabama & Birmingham & $2002-2005$ & 3 & 0.349 & 0.036 \\
\hline Southern District of Alabama & Mobile & $2002-2005$ & 2 & 0.464 & 0.006 \\
\hline Southern District of California & San Diego & 2002-2005 & 4 & 0.472 & 0.011 \\
\hline Southern District of Florida & Fort Lauderdale & 2002-2005 & 2 & 0.448 & 0.006 \\
\hline Southern District of Florida & Miami & 2002-2005 & 2 & 0.537 & 0.007 \\
\hline Northern District of Georgia & Atlanta & 2004-2005 & 8 & 0.322 & 0.035 \\
\hline Northern District of Georgia & Rome & 2004-2005 & 2 & 0.414 & 0.015 \\
\hline District of Idaho & Boise & 2002-2005 & 2 & 0.548 & 0.006 \\
\hline Southern District of Indiana & Indianapolis & $2002-2005$ & 3 & 0.529 & 0.006 \\
\hline Eastern District of Kentucky & Lexington & 2002-2005 & 2 & 0.556 & 0.034 \\
\hline District of Massachusetts & Boston & $2002-2003$ & 3 & 0.334 & 0.036 \\
\hline Eastern District of Michigan & Detroit & 2003-2005 & 3 & 0.299 & 0.001 \\
\hline Western District of Michigan & Grand Rapids & $2002-2005$ & 3 & 0.507 & 0.010 \\
\hline District of Minnesota & Minneapolis & 2002-2005 & 2 & 0.530 & 0.001 \\
\hline District of Minnesota & St. Paul & 2002-2005 & 2 & 0.543 & 0.044 \\
\hline Eastern District of Missouri & St. Louis & 2003-2005 & 2 & 0.422 & 0.019 \\
\hline Western District of Missouri & Kansas City & 2002-2005 & 4 & 0.505 & 0.011 \\
\hline Middle District of North Carolina & Durham & 2005 & 2 & 0.568 & 0.017 \\
\hline District of New Mexico & Albuquerque & 2002-2005 & 2 & 0.419 & 0.022 \\
\hline District of Nevada & Las Vegas & 2002-2005 & 3 & 0.389 & 0.011 \\
\hline Southern District of Ohio & Cincinnati & 2002-2005 & 3 & 0.570 & 0.025 \\
\hline Southern District of Ohio & Columbus & 2002 & 3 & 0.600 & 0.057 \\
\hline Southern District of Ohio & Dayton & $2002-2005$ & 3 & 0.609 & 0.022 \\
\hline Northern District of Oklahoma & Tulsa & $2002-2005$ & 2 & 0.480 & 0.011 \\
\hline District of Oregon & Eugene & $2002-2005$ & 2 & 0.600 & 0.016 \\
\hline District of Oregon & Portland & $2002-2005$ & 3 & 0.551 & 0.114 \\
\hline District of South Carolina & Columbia & 2003-2005 & 2 & 0.758 & 0.021 \\
\hline Eastern District of Tennessee & Chattanooga & $2002-2005$ & 2 & 0.443 & 0.009 \\
\hline Middle District of Tennessee & Columbia & 2002-2005 & 3 & 0.469 & 0.010 \\
\hline Middle District of Tennessee & Cookeville & 2002-2005 & 3 & 0.476 & 0.014 \\
\hline Middle District of Tennessee & Nashville & 2002-2005 & 3 & 0.493 & 0.015 \\
\hline Western District of Tennessee & Memphis & 2002-2005 & 3 & 0.270 & 0.003 \\
\hline Western District of Texas & San Antonio & 2002-2005 & 2 & 0.443 & 0.002 \\
\hline District of Utah & Salt Lake City & 2003-2005 & 3 & 0.348 & 0.007 \\
\hline Eastern District of Virginia & Alexandria & 2002-2005 & 2 & 0.567 & 0.001 \\
\hline Eastern District of Virginia & Newport News & 2002-2005 & 2 & 0.569 & 0.038 \\
\hline Eastern District of Virginia & Norfolk & 2002-2005 & 2 & 0.597 & 0.001 \\
\hline Western District of Washington & Tacoma & 2002-2005 & 2 & 0.574 & 0.004 \\
\hline Eastern District of Wisconsin & Milwaukee & 2003-2005 & 3 & 0.472 & 0.010 \\
\hline
\end{tabular}

Notes: This table presents descriptive statistics for the 39 offices in the 29 bankruptcy courts that randomly assign filings to judges in our instrumental variables sample. $\sigma_{Z}$ is the standard deviation of leave-one-out measure of judge leniency described in the text. 
Appendix Table 2

Results for Alternative Financial Strain Measures

\begin{tabular}{|c|c|c|c|}
\hline \multirow{3}{*}{$\begin{array}{l}\text { Panel A: Ever Experienced } \\
\text { Delinquency }\end{array}$} & \multirow{2}{*}{$\begin{array}{c}\begin{array}{c}\text { Dismissed } \\
\text { Mean }\end{array} \\
(1)\end{array}$} & \multicolumn{2}{|c|}{ 2SLS Results } \\
\hline & & $(2)$ & $(3)$ \\
\hline & $\begin{array}{c}0.942 \\
(0.233)\end{array}$ & $\begin{array}{c}0.002 \\
(0.027)\end{array}$ & $\begin{array}{r}-0.007 \\
(0.026)\end{array}$ \\
\hline Collection & $\begin{array}{c}0.920 \\
(0.271)\end{array}$ & $\begin{array}{c}-0.147^{* *} \\
(0.061)\end{array}$ & $\begin{array}{r}-0.098 \\
(0.066)\end{array}$ \\
\hline Charge-off ${ }^{\dagger}$ & $\begin{array}{c}0.581 \\
(0.493)\end{array}$ & $\begin{array}{r}-0.112^{*} \\
(0.060)\end{array}$ & $\begin{array}{r}-0.120^{*} \\
(0.065)\end{array}$ \\
\hline New Bankruptcy ${ }^{\dagger}$ & $\begin{array}{c}0.351 \\
(0.477)\end{array}$ & $\begin{array}{l}-0.271^{* * *} \\
(0.056)\end{array}$ & $\begin{array}{l}-0.278^{* * *} \\
(0.060)\end{array}$ \\
\hline Foreclosure & $\begin{array}{c}0.248 \\
(0.432)\end{array}$ & $\begin{array}{l}-0.111^{* * *} \\
(0.031)\end{array}$ & $\begin{array}{c}-0.062^{* *} \\
(0.025)\end{array}$ \\
\hline Judgment & $\begin{array}{c}0.252 \\
(0.434)\end{array}$ & $\begin{array}{l}-0.154^{* * *} \\
(0.056)\end{array}$ & $\begin{array}{c}-0.127^{* *} \\
(0.058)\end{array}$ \\
\hline Lien & $\begin{array}{c}0.128 \\
(0.334)\end{array}$ & $\begin{array}{l}-0.116^{* * *} \\
(0.026)\end{array}$ & $\begin{array}{l}-0.111^{* * *} \\
(0.028)\end{array}$ \\
\hline Repossession & $\begin{array}{c}0.084 \\
(0.278)\end{array}$ & $\begin{array}{l}-0.071^{* * *} \\
(0.027)\end{array}$ & $\begin{array}{c}-0.074^{* *} \\
(0.029)\end{array}$ \\
\hline \multicolumn{4}{|c|}{ Panel B: Number of Experiences } \\
\hline Delinquencies & $\begin{array}{c}6.774 \\
(5.434)\end{array}$ & $\begin{array}{r}1.247^{*} \\
(0.650)\end{array}$ & $\begin{array}{c}0.719 \\
(0.688)\end{array}$ \\
\hline Collections & $\begin{array}{c}6.847 \\
(6.722)\end{array}$ & $\begin{array}{l}-2.992^{* * *} \\
(0.624)\end{array}$ & $\begin{array}{l}-2.235^{* * *} \\
(0.750)\end{array}$ \\
\hline Charge-offs $^{\dagger}$ & $\begin{array}{c}1.220 \\
(1.562)\end{array}$ & $\begin{array}{l}-0.364^{* * *} \\
(0.110)\end{array}$ & $\begin{array}{l}-0.395^{* * *} \\
(0.130)\end{array}$ \\
\hline New Bankruptcies ${ }^{\dagger}$ & $\begin{array}{c}0.479 \\
(0.772)\end{array}$ & $\begin{array}{l}-0.336^{* * *} \\
(0.103)\end{array}$ & $\begin{array}{c}-0.339^{* * *} \\
(0.110)\end{array}$ \\
\hline Foreclosures & $\begin{array}{c}0.369 \\
(0.767)\end{array}$ & $\begin{array}{l}-0.158^{* * *} \\
(0.047)\end{array}$ & $\begin{array}{r}-0.077^{*} \\
(0.045)\end{array}$ \\
\hline Judgments & $\begin{array}{c}0.384 \\
(0.836)\end{array}$ & $\begin{array}{l}-0.304^{* * *} \\
(0.090)\end{array}$ & $\begin{array}{l}-0.262^{* * *} \\
(0.093)\end{array}$ \\
\hline Liens & $\begin{array}{c}0.237 \\
(1.069)\end{array}$ & $\begin{array}{l}-0.283^{* * *} \\
(0.102)\end{array}$ & $\begin{array}{c}-0.275^{* *} \\
(0.111)\end{array}$ \\
\hline Repossessions & $\begin{array}{c}0.094 \\
(0.329)\end{array}$ & $\begin{array}{c}-0.076^{* *} \\
(0.034)\end{array}$ & $\begin{array}{c}-0.078^{* *} \\
(0.036)\end{array}$ \\
\hline Controls & - & No & Yes \\
\hline Observations & 97006 & 175076 & 175076 \\
\hline
\end{tabular}

Notes: This table reports two-stage least squares results of the impact of Chapter 13 bankruptcy protection for alternative versions of the financial strain variables. All outcomes are annual averages for the year of filing to fifth year post-filing, with the exceptions of outcomes with a $\dagger$ where outcomes are averaged over the first full year after filing to the fifth year post-filing to remove the mechanical effect of the bankruptcy filing. Panel A reports results for indicator variables equal to one if the listed event occurred at least once in the first five post-filing years. Panel B reports results for the number of times the listed event occurred in the first five post-filing years. See Table 3 notes for additional details. ${ }^{* * *}=$ significant at 1 percent level, ${ }^{* *}=$ significant at 5 percent level, ${ }^{*}=$ significant at 10 percent level. 


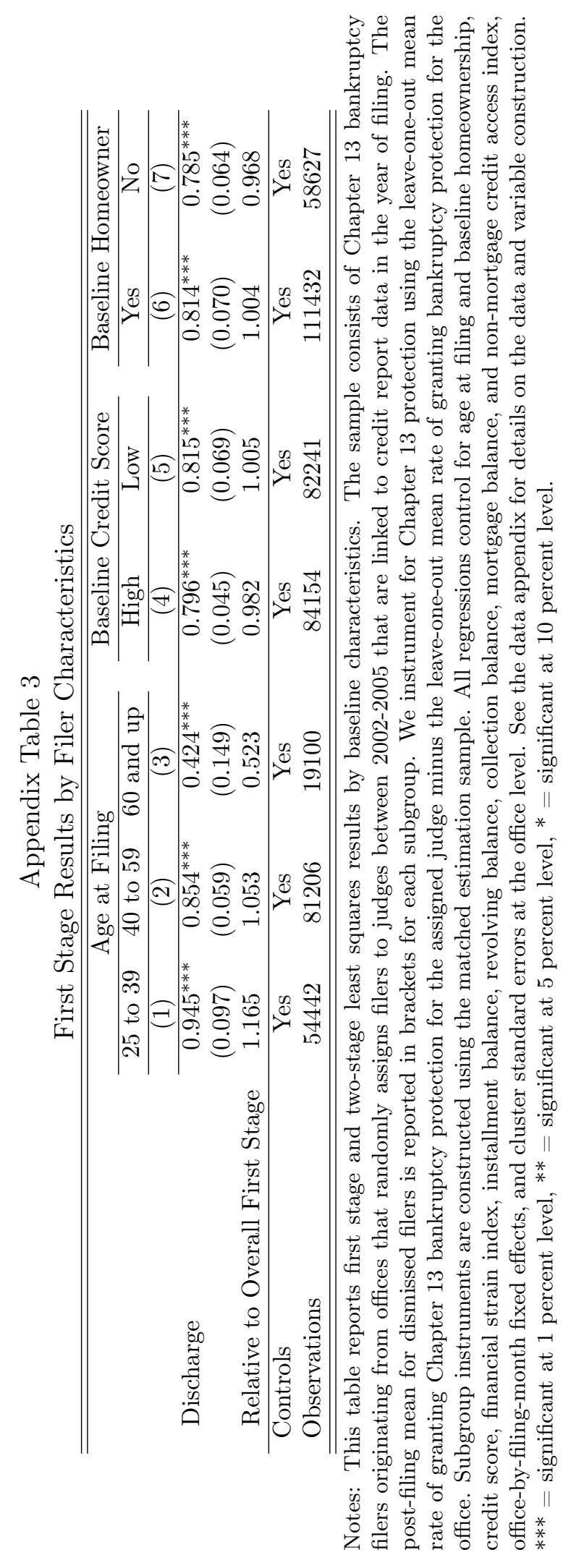


Appendix Table 4

Results for Additional Outcomes

\begin{tabular}{|c|c|c|c|}
\hline \multirow{3}{*}{$\begin{array}{l}\text { Panel A: Adverse Financial Events } \\
\text { Number of Paid Collections }\end{array}$} & \multirow{2}{*}{$\begin{array}{c}\begin{array}{c}\text { Dismissed } \\
\text { Mean }\end{array} \\
(1)\end{array}$} & \multicolumn{2}{|c|}{ 2SLS Results } \\
\hline & & $(2)$ & $(3)$ \\
\hline & $\begin{array}{c}0.744 \\
(1.266)\end{array}$ & $\begin{array}{l}-0.336^{* * *} \\
(0.057)\end{array}$ & $\begin{array}{l}-0.224^{* * *} \\
(0.051)\end{array}$ \\
\hline Number of Unpaid Collections & $\begin{array}{c}4.251 \\
(4.374)\end{array}$ & $\begin{array}{l}-1.899^{* * *} \\
(0.475)\end{array}$ & $\begin{array}{c}-1.296^{* *} \\
(0.528)\end{array}$ \\
\hline Number of Medical Collections & $\begin{array}{c}0.513 \\
(0.942)\end{array}$ & $\begin{array}{r}-0.077 \\
(0.090)\end{array}$ & $\begin{array}{r}-0.004 \\
(0.101)\end{array}$ \\
\hline Number of Paid Judgments & $\begin{array}{c}0.087 \\
(0.338)\end{array}$ & $\begin{array}{c}-0.051^{* *} \\
(0.023)\end{array}$ & $\begin{array}{r}-0.032 \\
(0.025)\end{array}$ \\
\hline Number of Unpaid Judgments & $\begin{array}{c}0.560 \\
(0.977)\end{array}$ & $\begin{array}{l}-0.339^{* * *} \\
(0.107)\end{array}$ & $\begin{array}{c}-0.238^{* *} \\
(0.102)\end{array}$ \\
\hline \multicolumn{4}{|l|}{ Panel B: Student Debt } \\
\hline Any Active Student Debt & $\begin{array}{c}0.167 \\
(0.343)\end{array}$ & $\begin{array}{c}0.003 \\
(0.057)\end{array}$ & $\begin{array}{c}0.026 \\
(0.050)\end{array}$ \\
\hline Any Deferred Student Debt & $\begin{array}{c}0.038 \\
(0.154)\end{array}$ & $\begin{array}{c}-0.015 \\
(0.027)\end{array}$ & $\begin{array}{c}-0.010 \\
(0.026)\end{array}$ \\
\hline \multicolumn{4}{|l|}{ Panel C: Home Transitions } \\
\hline Living in Same Residence & $\begin{array}{c}0.496 \\
(0.500)\end{array}$ & $\begin{array}{l}0.270^{* * *} \\
(0.049)\end{array}$ & $\begin{array}{l}0.250^{* * *} \\
(0.054)\end{array}$ \\
\hline Moved to Rental & $\begin{array}{l}0.429 \\
(0.495)\end{array}$ & $\begin{array}{l}-0.267^{* * *} \\
(0.065)\end{array}$ & $\begin{array}{l}-0.250^{* * *} \\
(0.059)\end{array}$ \\
\hline Move to Home & $\begin{array}{c}0.075 \\
(0.263)\end{array}$ & $\begin{array}{r}-0.003 \\
(0.040)\end{array}$ & $\begin{array}{r}-0.001 \\
(0.040)\end{array}$ \\
\hline \multicolumn{4}{|l|}{ Panel D: Revolving Trades } \\
\hline Number of Open Revolving Trades & $\begin{array}{c}0.766 \\
(1.312)\end{array}$ & $\begin{array}{l}0.576^{* * *} \\
(0.144)\end{array}$ & $\begin{array}{l}0.321^{* *} \\
(0.130)\end{array}$ \\
\hline Credit Limit Revolving Trades & $\begin{array}{c}6.083 \\
(12.691)\end{array}$ & $\begin{array}{l}3.362^{* * *} \\
(1.256)\end{array}$ & $\begin{array}{c}-0.599 \\
(0.801)\end{array}$ \\
\hline Controls & - & No & Yes \\
\hline Observations & 97006 & 175076 & 175076 \\
\hline
\end{tabular}

Notes: This table reports two-stage least squares results of the impact of Chapter 13 bankruptcy protection on additional outcomes available in the credit bureau data. The sample consists of Chapter 13 bankruptcy filers originating from offices that randomly assigns filers to judges between 2002-2005 that are linked to credit report data in the year of filing. All outcomes are measured over the first five post-filing years. Column 1 reports the post-filing mean and standard deviation for dismissed filers. Columns 2-3 instrument for Chapter 13 protection using the leave-one-out mean rate of granting Chapter 13 bankruptcy protection for the assigned judge minus the leave-one-out mean rate of granting bankruptcy protection for the office. All regressions control for office-by-filing-month fixed effects and cluster standard errors at the office level. Column 3 adds controls for baseline age bins, homeownership, credit score, financial strain index, revolving balance, collection balance, mortgage balance, auto balance, indicators for mortgage and auto loans, revolving utilization, and non-mortgage inquiries as controls. $* * *=$ significant at 1 percent level, $* *$ $=$ significant at 5 percent level, $*=$ significant at 10 percent level. 
Appendix Table 5

Results by State Judicial Foreclosure Laws

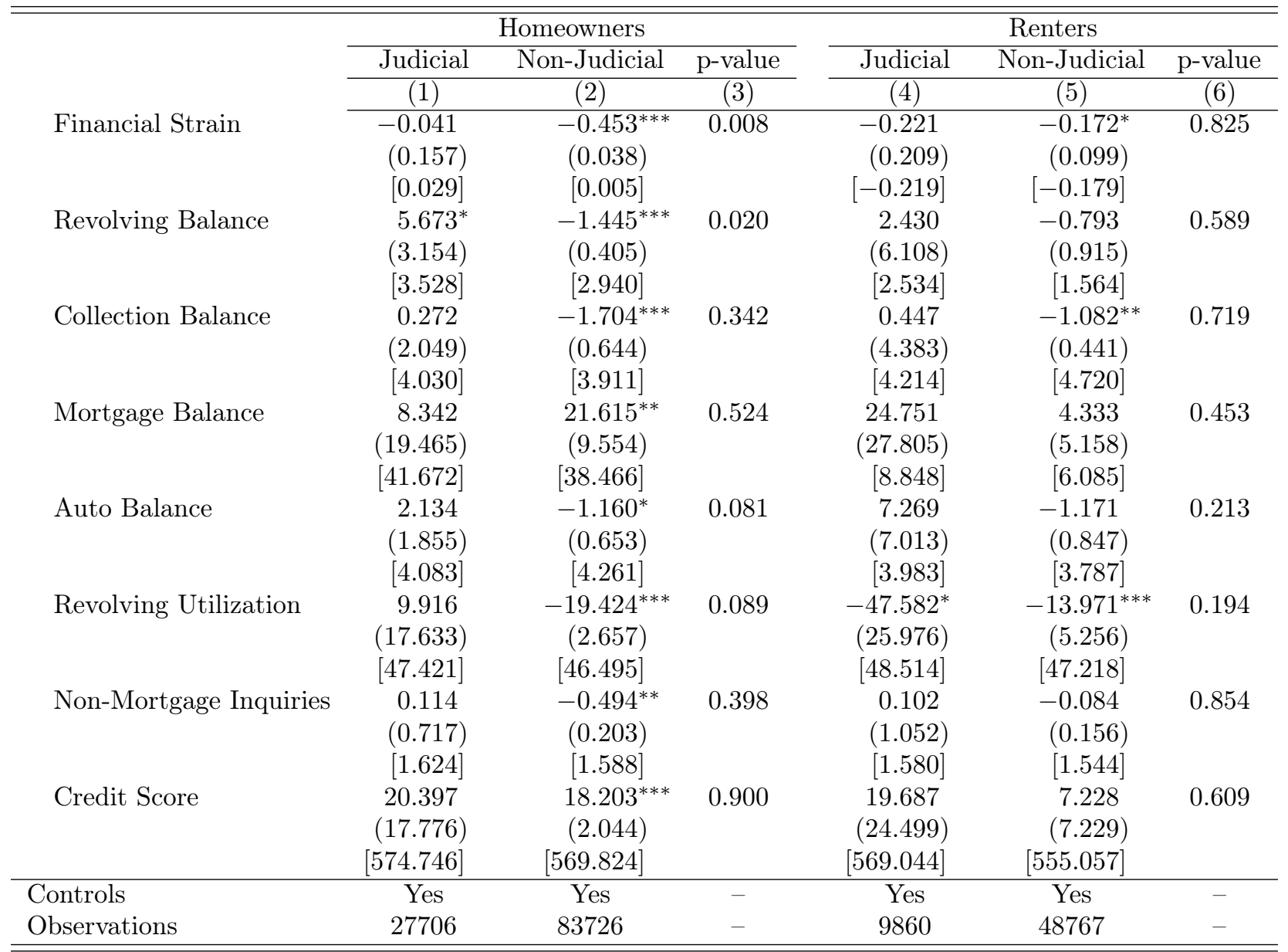

Notes: This table reports two-stage least squares results of the impact of Chapter 13 bankruptcy protection for states with judicial foreclosure and those without judicial foreclosure, separately by homeownership status. The sample consists of Chapter 13 bankruptcy filers originating from offices that randomly assigns filers to judges between 20022005 that are linked to credit report data in the year of filing. The post-filing mean for dismissed filers is reported in brackets for each subgroup. We instrument for Chapter 13 protection using the leave-one-out mean rate of granting Chapter 13 bankruptcy protection for the assigned judge minus the leave-one-out mean rate of granting bankruptcy protection for the office. Subgroup instruments are constructed using the matched estimation sample. All regressions control for baseline age bins, homeownership, credit score, financial strain index, revolving balance, collection balance, mortgage balance, auto balance, indicators for mortgage and auto loans, revolving utilization, non-mortgage inquiries, office-by-filing-month fixed effects, and cluster standard errors at the office level. See the data appendix for details on the data and variable construction. ${ }^{* * *}=$ significant at 1 percent level, $* *=$ significant at 5 percent level, $*=$ significant at 10 percent level. 


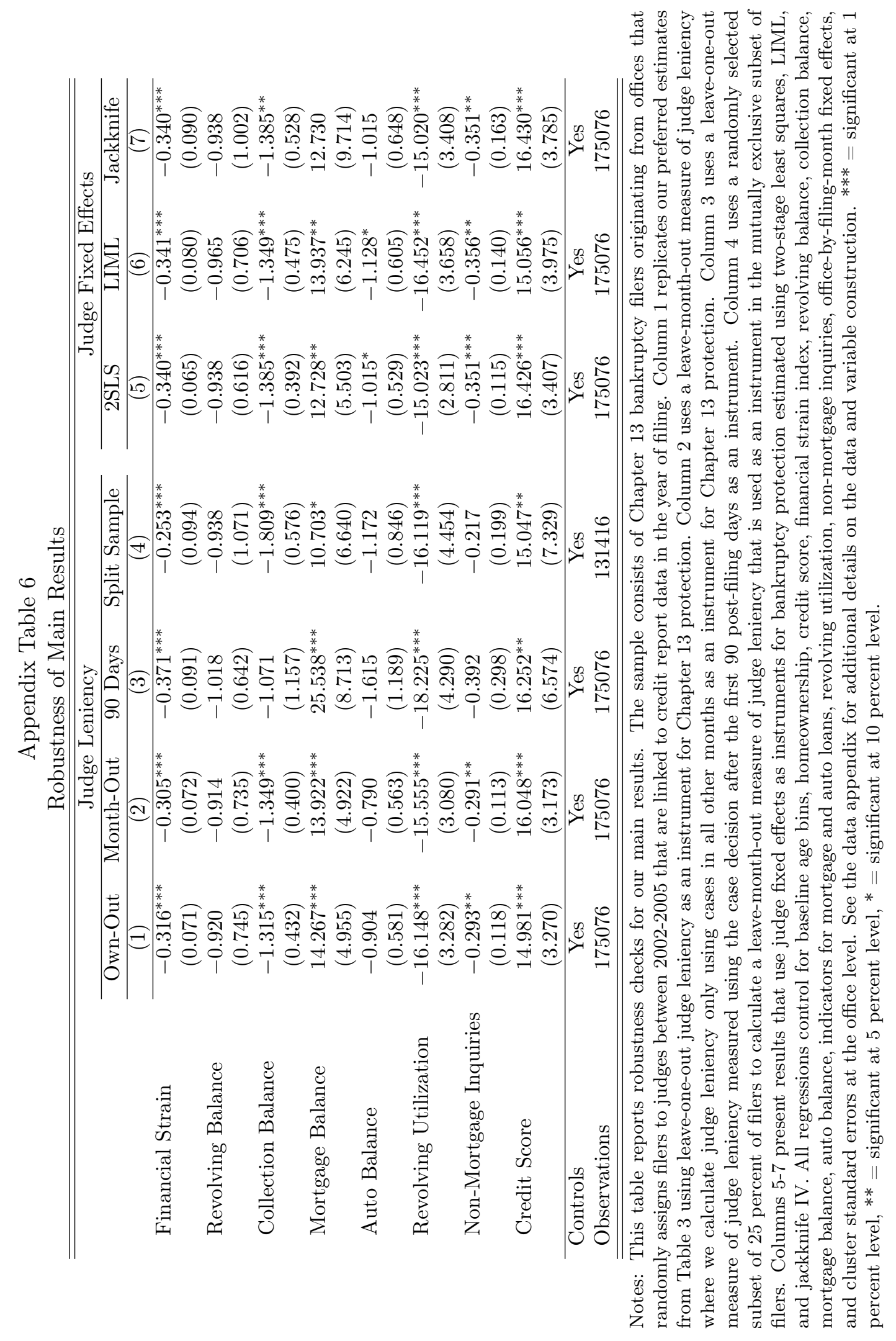


Appendix Table 7

Results in the Sixth to Eighth Post-Filing Years

\begin{tabular}{|c|c|c|c|}
\hline & \multicolumn{3}{|l|}{ Dismissed } \\
\hline \multirow{3}{*}{ Financial Strain Index } & (1) & $(2)$ & $(3)$ \\
\hline & -0.416 & $-0.216^{* * *}$ & $-0.127^{* *}$ \\
\hline & $(0.777)$ & $(0.055)$ & $(0.054)$ \\
\hline \multirow[t]{2}{*}{ Revolving Balance } & 1.014 & $0.697^{*}$ & 0.094 \\
\hline & $(3.878)$ & $(0.360)$ & $(0.348)$ \\
\hline \multirow[t]{2}{*}{ Collection Balance } & 4.666 & $-2.534^{* * *}$ & $-1.931^{* * *}$ \\
\hline & $(7.376)$ & $(0.563)$ & $(0.599)$ \\
\hline \multirow[t]{2}{*}{ Have a Mortgage } & 0.184 & $0.259^{* * *}$ & $0.260^{* * *}$ \\
\hline & $(0.371)$ & $(0.032)$ & $(0.028)$ \\
\hline \multirow[t]{2}{*}{ Mortgage Balance } & 15.861 & $34.967^{* * *}$ & $36.780^{* * *}$ \\
\hline & $(48.046)$ & $(11.495)$ & $(13.654)$ \\
\hline \multirow[t]{2}{*}{ Have an Auto Loan } & 0.190 & $0.127^{* * *}$ & $0.126^{* * *}$ \\
\hline & $(0.367)$ & $(0.041)$ & $(0.045)$ \\
\hline \multirow[t]{2}{*}{ Auto Balance } & 3.518 & 0.641 & 0.486 \\
\hline & $(6.972)$ & $(0.655)$ & $(0.700)$ \\
\hline \multirow[t]{2}{*}{ Revolving Utilization } & 34.362 & -8.942 & -8.601 \\
\hline & $(53.460)$ & $(8.636)$ & $(9.178)$ \\
\hline \multirow[t]{2}{*}{ Non-Mortgage Inquiries } & 0.974 & -0.107 & -0.037 \\
\hline & $(1.375)$ & $(0.184)$ & $(0.196)$ \\
\hline \multirow[t]{2}{*}{ Credit Score } & 576.720 & $45.603^{* * *}$ & $28.792^{* * *}$ \\
\hline & $(57.229)$ & $(7.761)$ & $(6.609)$ \\
\hline Controls & - & No & Yes \\
\hline Observations & 83792 & 151655 & 151655 \\
\hline
\end{tabular}

Notes: This table reports two-stage least squares results of the impact of Chapter 13 bankruptcy protection on postfiling outcomes in the sixth through eighth post-filing years. The sample consists of Chapter 13 bankruptcy filers originating from offices that randomly assigns filers to judges between 2002-2005 that are linked to credit report data in the year of filing and at least one observation in the sixth through eighth post-filing years. Column 1 reports the post-filing mean and standard deviation for dismissed filers. Columns 2-3 instrument for Chapter 13 protection using the leave-one-out mean rate of granting Chapter 13 bankruptcy protection for the assigned judge minus the leave-oneout mean rate of granting bankruptcy protection for the office. All regressions control for office-by-filing-month fixed effects and cluster standard errors at the office level. Column 3 adds controls for baseline age bins, homeownership, credit score, financial strain index, revolving balance, collection balance, mortgage balance, auto balance, indicators for mortgage and auto loans, revolving utilization, and non-mortgage inquiries as controls. See the data appendix for details on the data and variable construction. ${ }^{* * *}=$ significant at 1 percent level, ${ }^{* *}=$ significant at 5 percent level, $*$ = significant at 10 percent level. 
Appendix Figure 1

Persistence of Judge Leniency Measure

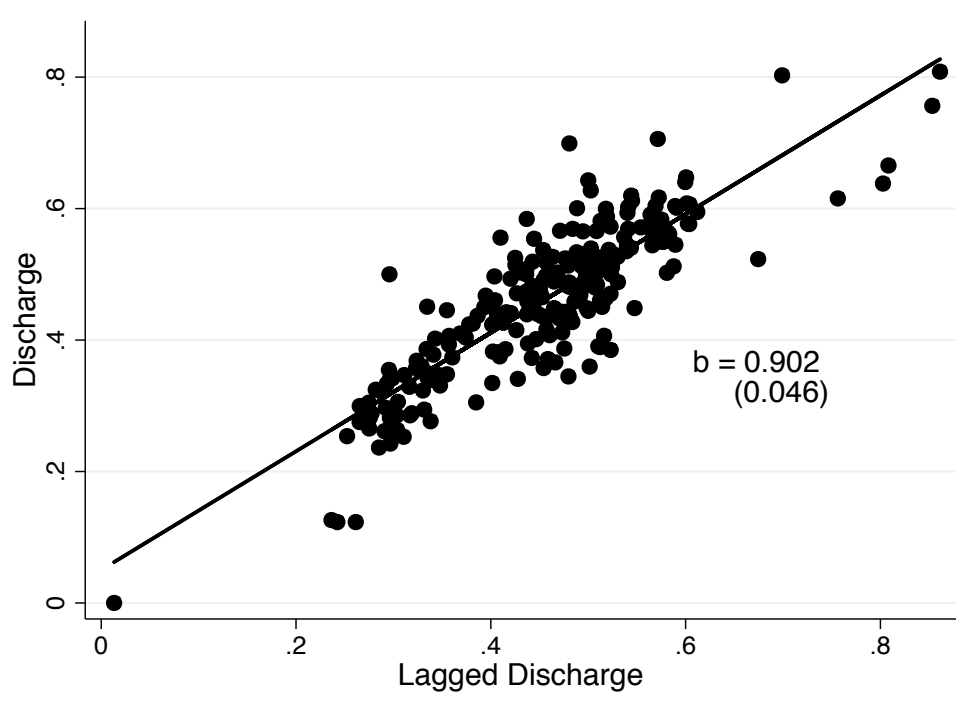

Notes: This figure plots current Chapter 13 discharge vs. lagged discharge for each judge-by-office-by-year. The sample consists of all first-time Chapter 13 filers from 2002-2005 linked to credit report data, for whom we observe credit data in the year of filing. Judge leniency is the leave-one-out mean rate of granting Chapter 13 bankruptcy protection for the assigned judge minus the leave-one-out mean rate of granting bankruptcy protection for the office. Each point in the scatter plot represents a separate judge-by-office-by-year observation. To construct the scatter plot, we regress current discharge rate on lagged discharge rate. The solid line shows the best linear fit estimated on the underlying micro data estimated using OLS. The coefficient shows the estimated slope of the best-fit line, with standard errors clustered at the office by judge level reported in parentheses. 
Appendix Figure 2

Judge Leniency and Bankruptcy Protection

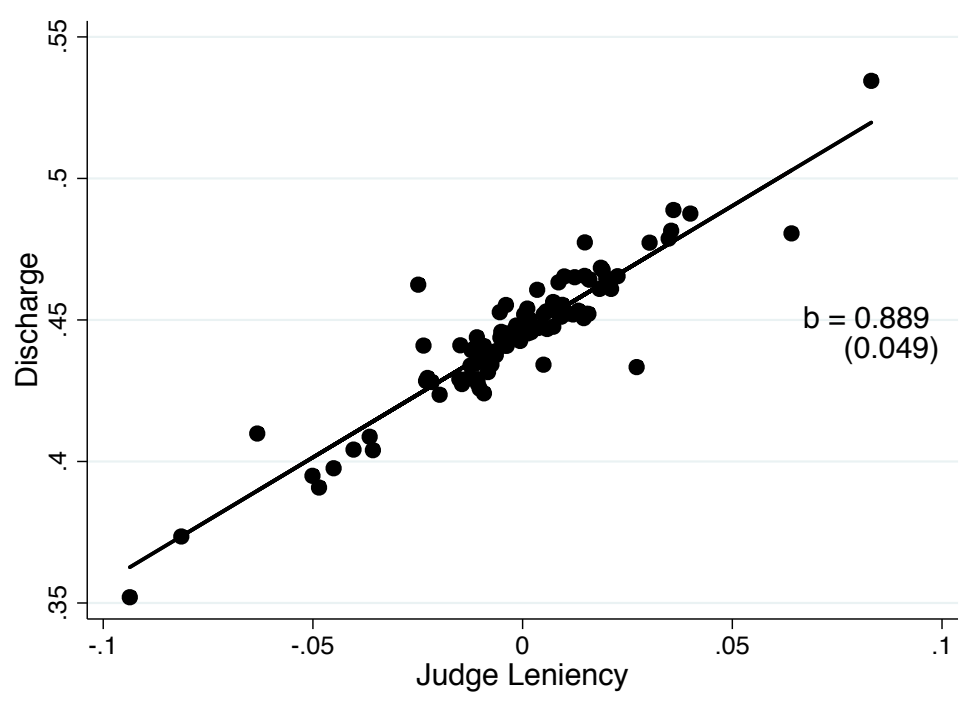

Notes: This figure plots Chapter 13 discharge vs. our leave-one-out measure of judge leniency. The sample consists of all first-time Chapter 13 filers from 2002-2005 linked to credit report data, for whom we observe credit data in the year of filing. Judge leniency is the leave-one-out mean rate of granting Chapter 13 bankruptcy protection for the assigned judge minus the leave-one-out mean rate of granting bankruptcy protection for the office. To construct the binned scatter plot, we first regress an indicator for discharge on office-by-filing-month fixed effects and calculate residuals. We then take the mean residual in each judge-by-year bin, adding the mean discharge rate to each residual to aid in the interpretation of the plot. The solid line shows the best linear fit estimated on the underlying micro data estimated using OLS. The coefficients show the estimated slope of the best-fit line including office-by-filing-month fixed effects, with standard errors clustered at the office level reported in parentheses. 
Appendix Figure 3

Judge Leniency by Filer Characteristics
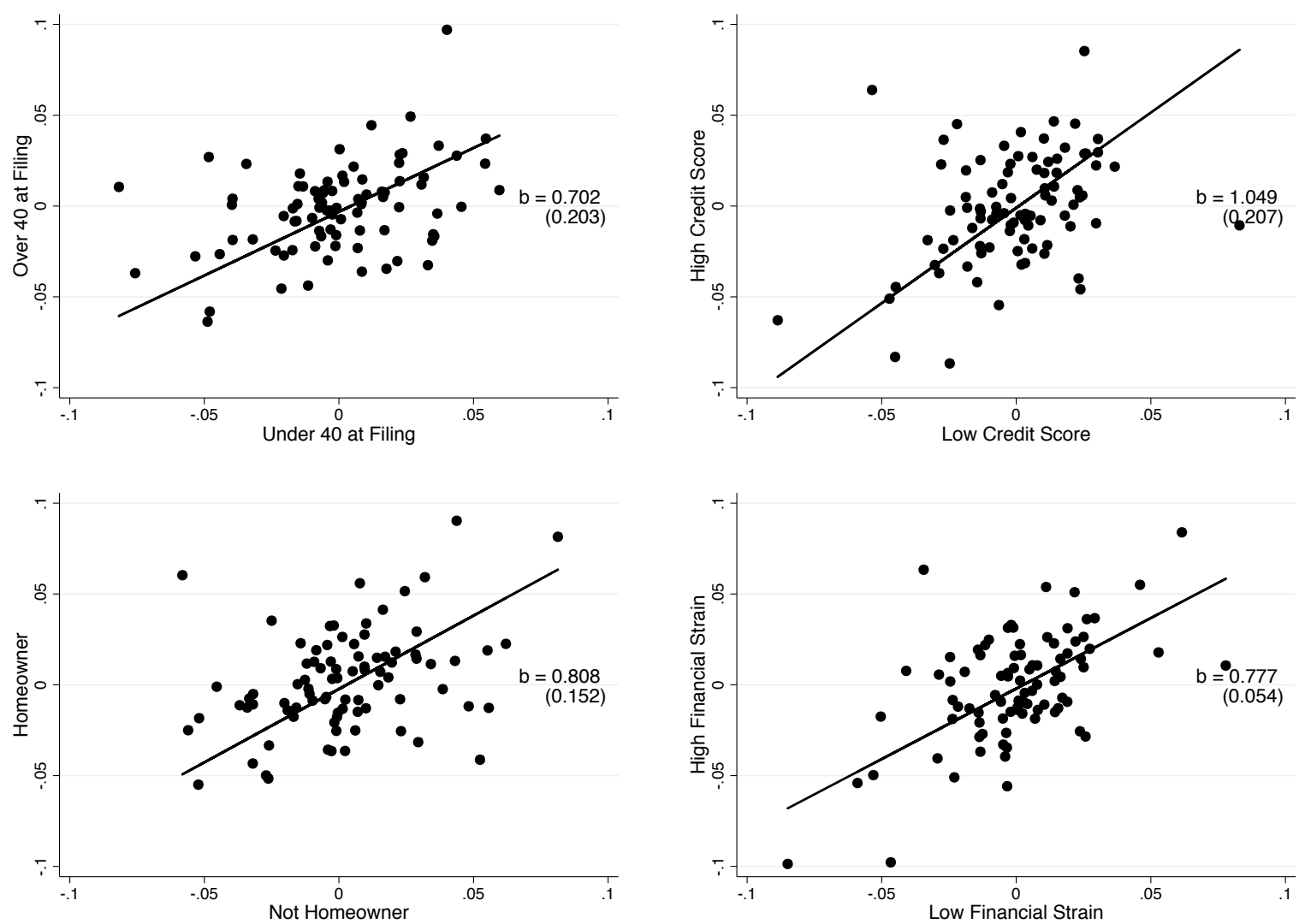

Notes: These figures show the correlation between judge leniency for different groups of filers. Age is determined at the time of filing, and credit score and homeownership are determined in the full year prior to filing. The sample consists of all first-time filers between June 2002 and 2005 in the 39 offices that randomly assign filings to judges. Judge leniency is defined as the leave-one-out mean rate of granting bankruptcy protection for the assigned judge minus the leave-one-out mean rate of granting bankruptcy protection for the office. We take the average leniency for each group over all available years of data. Subgroup instruments are constructed using the matched estimation sample. The solid line shows the best linear fit estimated using OLS relating each judge leniency measure. 
Appendix Figure 4

Trends by Filing Status

Delinquency

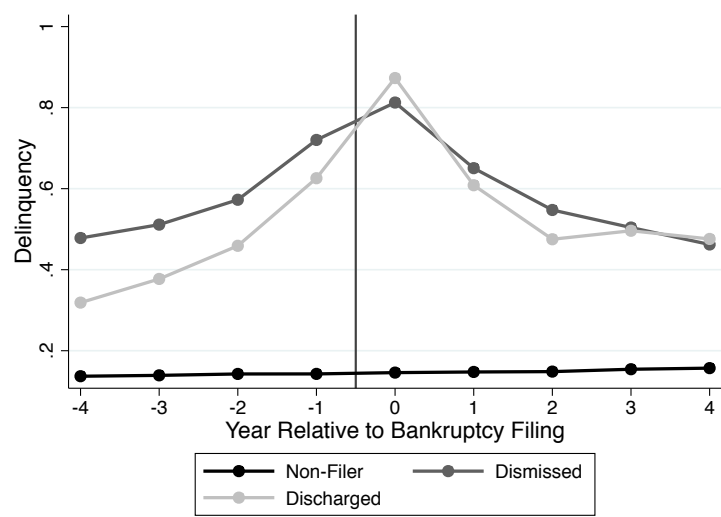

Charge-off

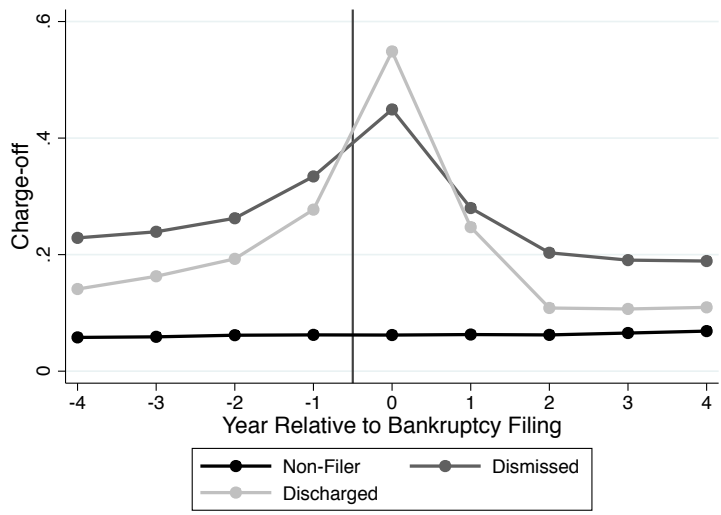

Foreclosure

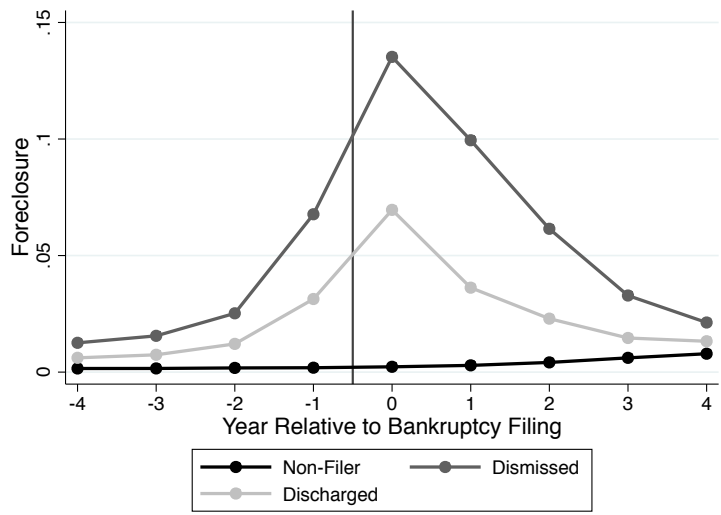

Collections

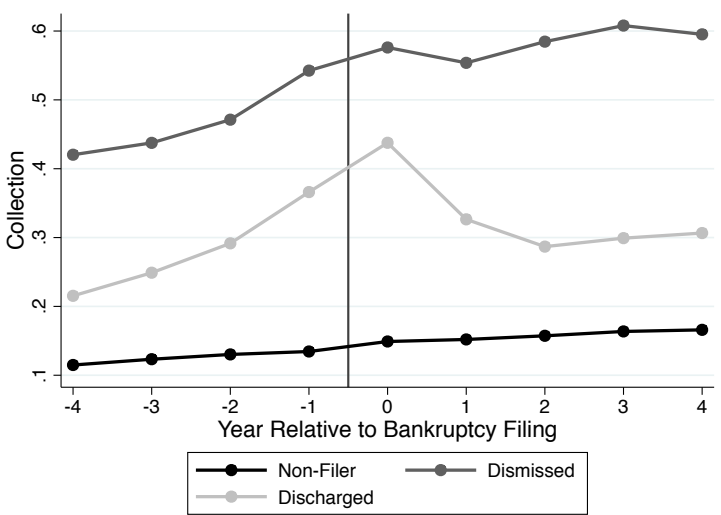

Bankruptcy

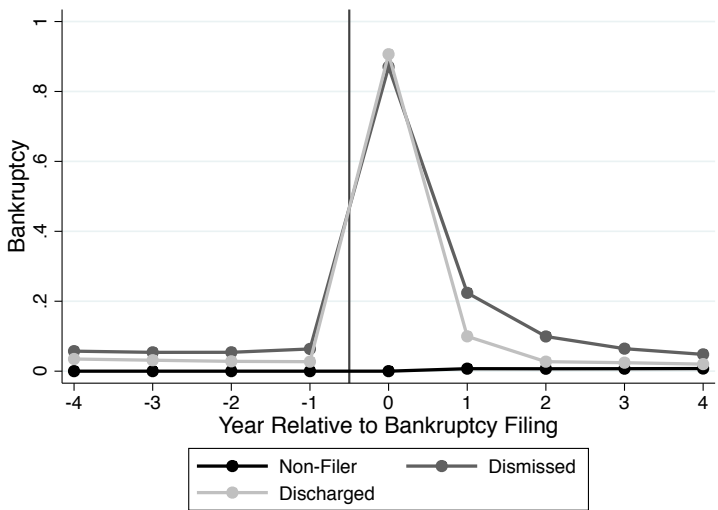

Judgment

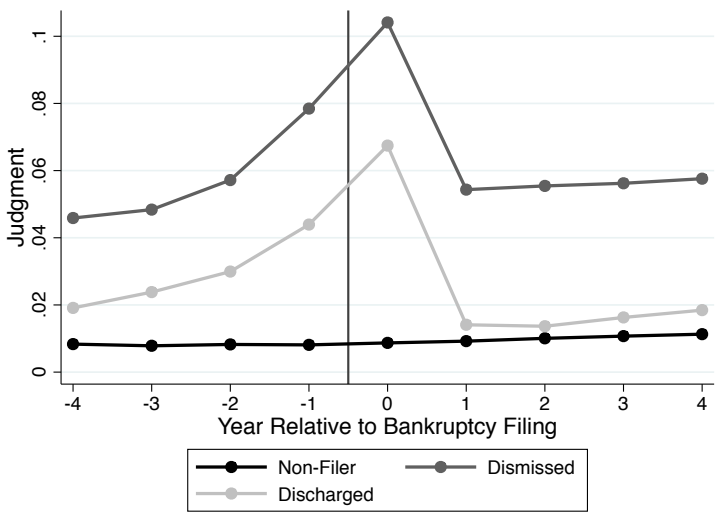

Notes: These figures show the coefficients on year relative to filing dummies interacted with filer status: non-filer, dismissed filer, and discharged filer. Raw data figures include no controls. 
Appendix Figure 4

Trends by Filing Status

Lien

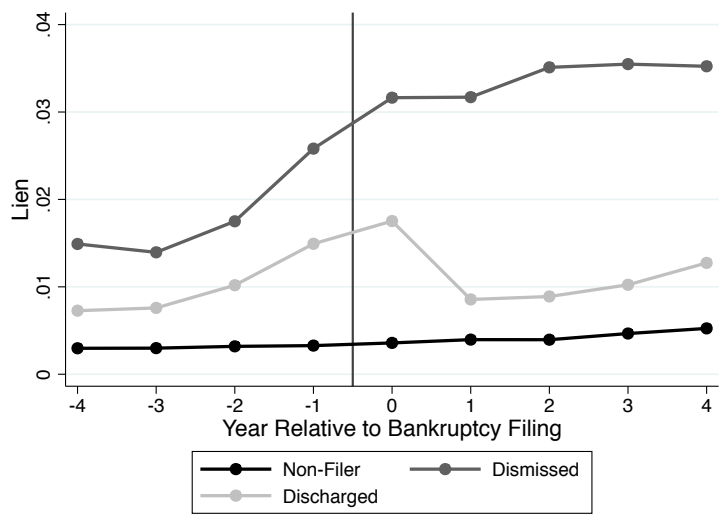

Revolving Balance

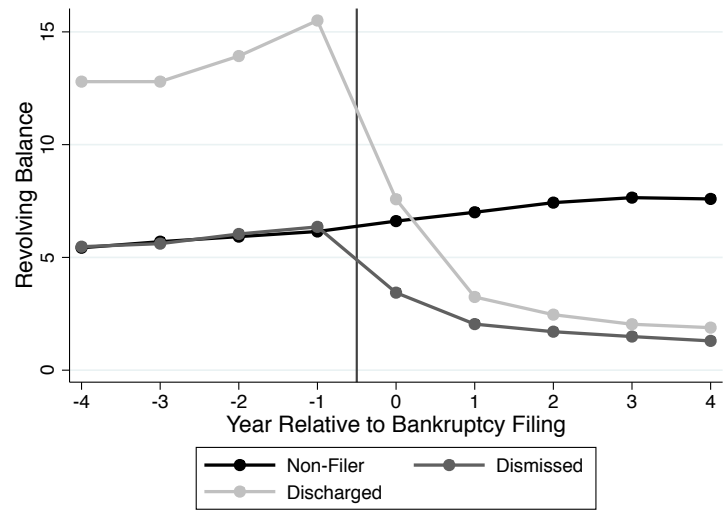

Open Mortgage

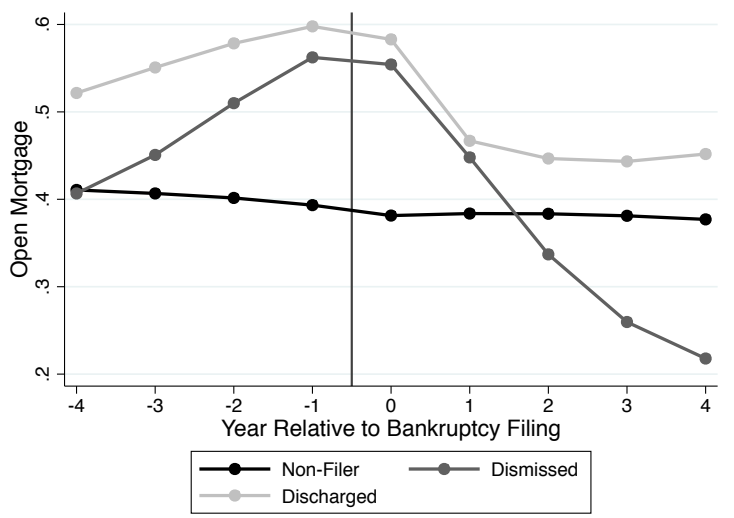

Repossession

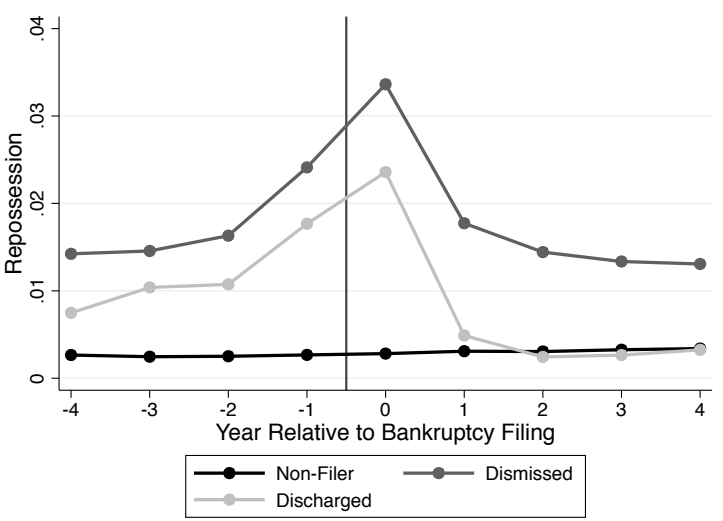

Collections Balance

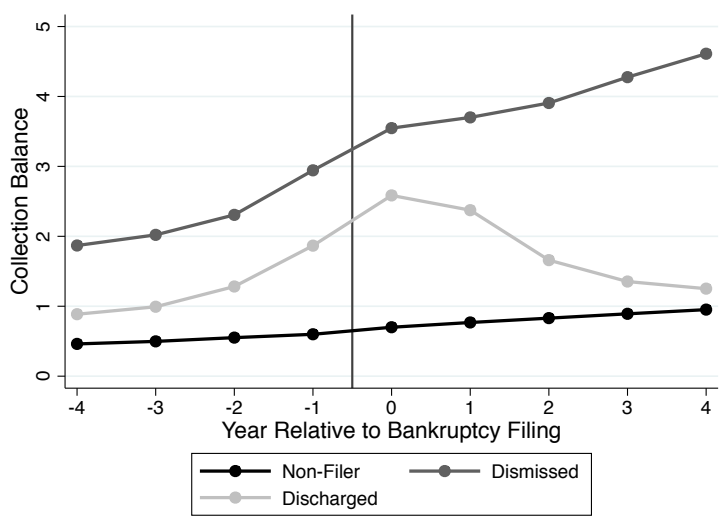

Mortgage Balance

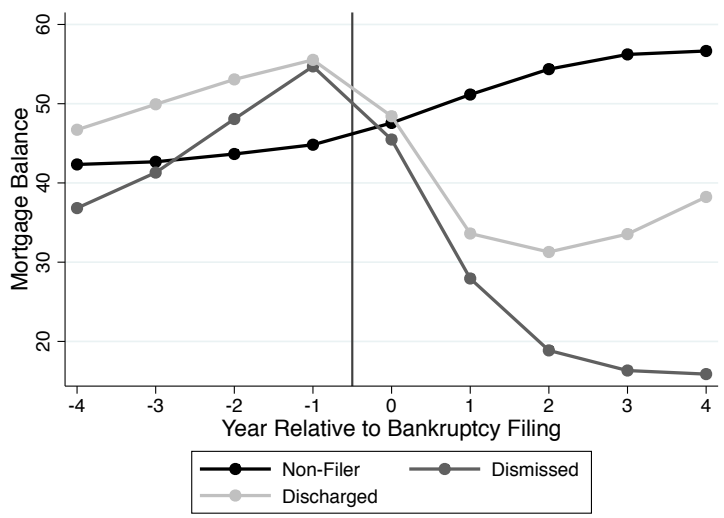

Notes: These figures show the coefficients on year relative to filing dummies interacted with filer status: non-filer, dismissed filer, and discharged filer. Raw data figures include no controls. 
Appendix Figure 4

Trends by Filing Status

Open Auto Loan

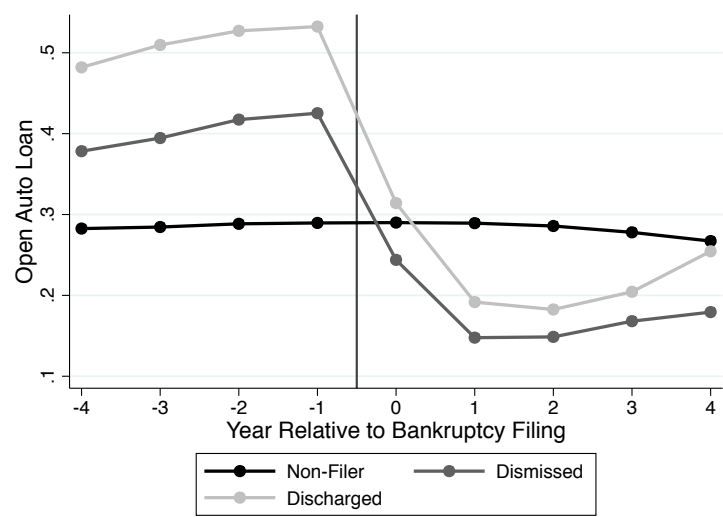

Utilization

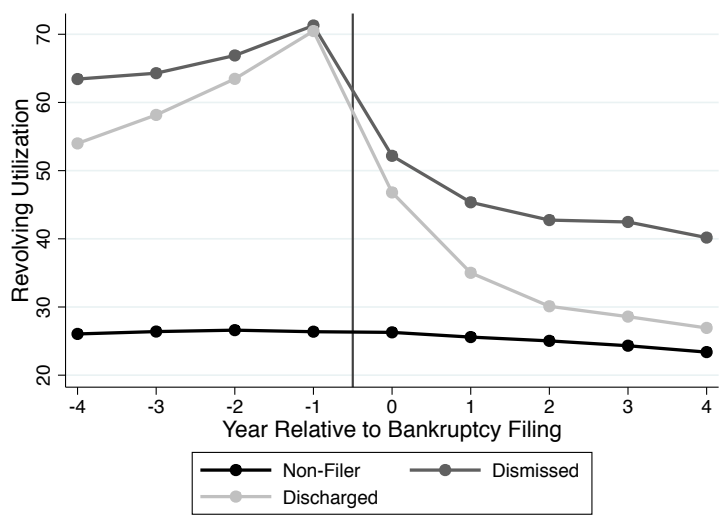

Credit Score

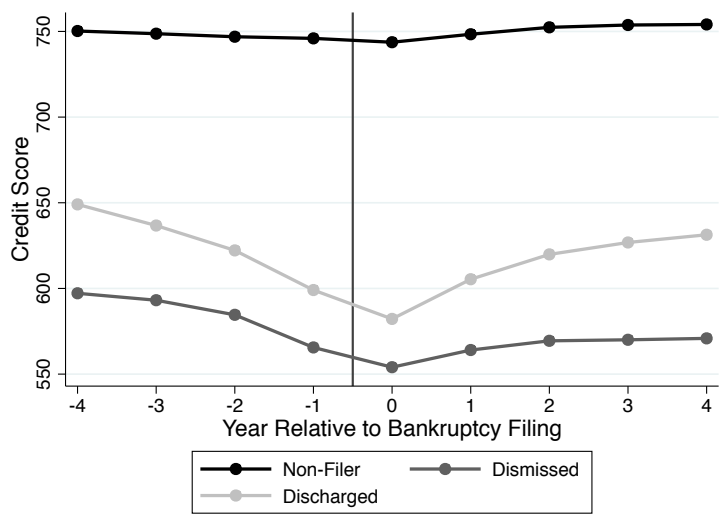

Auto Balance

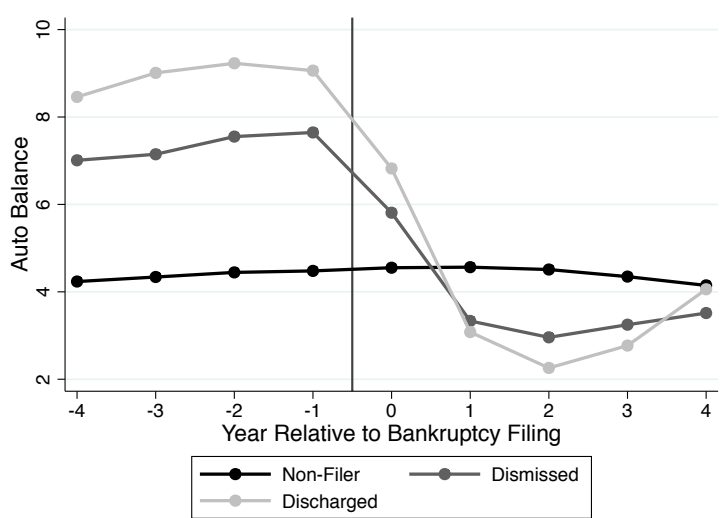

Non-Mortgage Inquiries

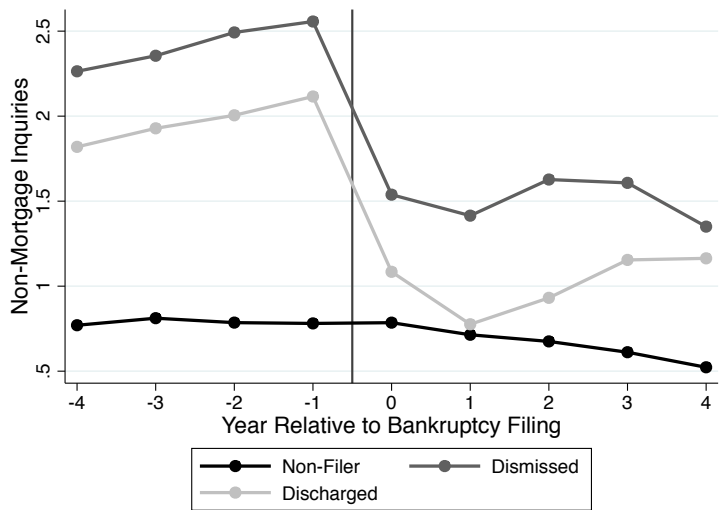

Financial Strain

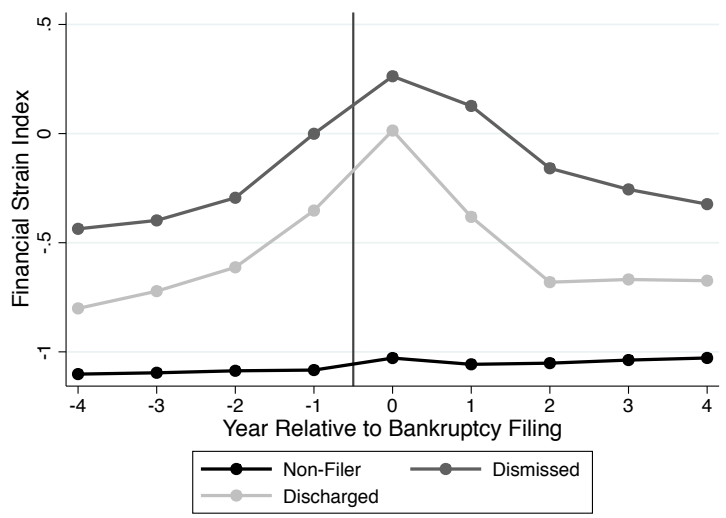

Notes: These figures show the coefficients on year relative to filing dummies interacted with filer status: non-filer, dismissed filer, and discharged filer. Raw data figures include no controls. 


\title{
VII. Data Dictionary
}

\author{
A. Judge Leniency
}

Judge Leniency - We calculate judge leniency as the leave-one-out mean rate of granting Chapter 13 bankruptcy protection for the assigned judge minus the leave-one-out mean rate of granting bankruptcy protection for the office.

\section{B. Characteristics}

Homeowner - Homeownership is based on a home flag calculated by TransUnion. The home flag is set to "Y" if there is any home equity or mortgage trade on file. This measure may overestimate actual homeownership because it does not require a non-zero balance on home equity or mortgage trades. Alternatively, this measure may underestimate actual homeownership if TransUnion does not observe the original mortgage or equity trade.

\section{Adverse Financial Events}

Delinquency - We measure post-filing delinquencies based on the number of trades currently $30+$ days past due within the past 12 months, provided by TransUnion. Delinquency probabilities are non-cumulative, measured as the probability of at least one delinquency in the prior 12 months, averaged over the first five post-filing years.

Collection - We measure post-filing collections based on the number of collection trades in the past 12 months, calculated by TransUnion. Collection account records consist of credit accounts and records of unpaid bills that have been transferred to a collection agency or in the process of collection. Generally, accounts sent to collection are listed on a debtor's credit report for seven years. Collection trades are trades either with KOB (Kind of Business) = Collection, MOP (Manner of Payment) = 9B (Collection), or remark/dispute flags such as "Collection account cancelled by creditor," "Placed for collection," and "Collection account." Collection probabilities are non-cumulative, measured as the probability of at least one collection in the prior 12 months, averaged over the first five post-filing years.

Charge-off - We measure post-filing charge-offs based on the number of charge-offs within the past 12 months, calculated by TransUnion. A charge-off occurs when a creditor declares a debt unlikely to be paid. An account is usually charged off after 180 days of non-payment, but the creditor can continue to attempt to collect on the debt. The charge-off record generally appears on a credit report for up to seven years. Charge-off information is obtained from trades with remark/dispute codes such as "Bad Debt: Collection Suit," "Claim/PMT Against Guarantor," "Early Termination w/Deficiency," "Skip out of Account," or MOP = 09 (Charged off to bad debt), or $\mathrm{MOP}=9 \mathrm{P}$ (Paying or paid account with MOP 09). Charge-off probabilities are non-cumulative, and can be thought of as the probability of at least one charge-off in the prior 12 months, averaged over the second to fifth post-filing years.

Bankruptcy - We measure post-filing bankruptcies based on the number of bankruptcies within the past 12 months, calculated by TransUnion. Bankruptcies can occur under Chapter 7, Chapter 11, Chapter 12, or Chapter 13. Bankruptcy probabilities are non-cumulative, measured as the probability of at least one bankruptcy in the prior 12 months, averaged over the second to fifth post-filing years. 
Foreclosure - We measure post-filing foreclosures based on the number of foreclosures within the past 12 months, calculated by TransUnion. A foreclosure is a process in which a bank or mortgage company takes possession of a mortgaged property because the mortgagor has failed to keep up with mortgage payments. Foreclosure information is obtained from public records, and trades with remark/dispute codes that signal foreclosure. In the TransUnion data, foreclosure is defined more expansively than an actual sale or deed transfer. Foreclosure ranges from an actual sale or transfer of the home, to merely a notice that foreclosure was commenced. For instance, the foreclosure flag is turned on for any of the following reasons: foreclosure initiated, foreclosure started, foreclosure discontinued, and foreclosure redeemed. Post-filing foreclosure probabilities are non-cumulative, and can be thought of as the probability of at least one foreclosure in the prior 12 months, averaged over the first five post-filing years.

Judgment - We measure post-filing judgments based on the number of civil judgment suits within the past 12 months, calculated by TransUnion. Judgment probabilities are noncumulative, measured as the probability of at least one judgment in the prior 12 months, averaged over the first five post-filing years.

Lien - We measure post-filing liens based on the number of lien public records within the past 12 months, calculated by TransUnion. A lien is an official claim against property or funds for payment of a debt owed. Public record liens include federal and state tax liens, hospital liens, and judicial liens. Lien probabilities are non-cumulative, measured as the probability of at least one lien in the prior 12 months, averaged over the first five post-filing years.

Repossession - We measure post-filing repossessions based on the number of repossessions within the past 12 months, calculated by TransUnion. A repossession occurs when a lender takes back an asset, such as an automobile. Repossessions can be voluntary or involuntary. Late payments leading up to repossession are damaging to a debtor's credit score, and the mark of a repossession appears on credit reports. In the TransUnion data, repossession information is obtained from trades with remark/dispute codes such as "Paid Respossession," "Reposession," "Repossession, redeemed," "Paid by dealer," "Paid from collateral," or MOP (Manner of Payment) $=08$ (Repossession). As with foreclosure, TransUnion defines repossessions expansively, including redeemed repossessions where the debtor makes full payment on the loan and takes back the asset. Post-filing repossession probabilities are non-cumulative, and can be thought of as the probability of at least one repossession in the prior 12 months, averaged over the first five post-filing years.

Financial Strain Index - The index contains the non-cumulative probabilities of the following eight components: delinquency, collection, charge-off, bankruptcy, foreclosure, judgment, lien and repossession, as defined above. Following Fryer and Katz (2013), for each post-filing year, each component is standardized using the mean and standard deviation for the dismissed filer group in the baseline year. We sum across the eight components to create a yearly index, restandardizing using the mean and standard deviation of the dismissed filer group in the baseline year. The index in the year of filing includes six components, excluding charge-offs and bankruptcies. We then average the yearly index across the first five post-filing years. Because each of the financial strains represent adverse events that negatively impact access to credit, a higher index represents worse outcomes. 


\section{Unsecured Debt and Collections Activity}

Revolving Balance - Total balance of revolving trades with current balance greater than zero verified within 6 months calculated by TransUnion. Revolving trades include bank card accounts, retail accounts, and check credit accounts. Retail trade accounts include clothing, department stores, grocery, home furnishings, jewelry, computer, camera, and sporting goods stores. According to Avery et al. (2003), revolving trade balances (dollar-weighted) represent 11 percent of all open account balances.

Collection Balance - Aggregate current balance of all collections on file calculated by TransUnion. There are two important shortcomings of the collections data. First, there is incomplete coverage of unpaid bills, with larger entities, such as hospitals and utility companies, more likely to send debts to collection agencies. Second, collection records will not include debts that parties collect themselves and debts sent to collection agencies that do not report to credit bureaus.

\section{E. Retaining Secured Assets}

Have a Mortgage - We measure the probability of having an open mortgage based on the number of open mortgage trades verified in the past 12 months calculated by TransUnion. Mortgage trades are loans such as conventional real estate mortgages, FHA loans, real estate loans, second mortgages, and VA loans.

Mortgage Balance - Total balance of all mortgage trades verified in the past 12 months calculated by TransUnion. According to Avery et al. (2003), mortgage balances (dollar-weighted) represent 67 percent of all open account balances.

Have an Auto Loan - We measure the probability of having an open auto loan based on the number of open auto loans verified in the past six months calculated by TransUnion. Auto loans typically involve fixed monthly payments that fully amortize the total amount borrowed over the term of the loan, often secured (Avery et al. 2003).

Auto Balance - Total balance of open auto trades verified in the past 12 months calculated by TransUnion.

\section{F. Credit Access}

Revolving Utilization - Total outstanding revolving trade balance divided by revolving trade credit limit verified in the past 12 months calculated by TransUnion, expressed in percentages. Because total credit limit is likely understates actual credit limits (Avery et al. 2003), the credit utilization rate likely overstates actual credit utilization.

Non-Mortgage Inquiries - Number of non-mortgage inquiries within the past 6 months calculated by TransUnion. Inquiries are made to ensure that an applicant for credit, apartment rental, insurance, or employment meets minimum standards. When a creditor or lender checks a debtor's credit in connection with an application, a "hard inquiry" is tagged on a credit report. A hard inquiry remains on a credit report for up to two years and may lower a debtor's credit score. When a creditor reviews the credit report of an existing customer, or when a debtor checks his own credit, a "soft inquiry" typically shows up on your credit report. Soft inquiries generally do not lower credit scores or appear to businesses checking a debtor's credit. 


\section{G. Credit Score}

Credit score - This measure is an ordinal credit score calculated by TransUnion to measure credit risk. This measure is similar to the FICO score commonly referenced in the consumer finance literature.

\section{H. Data Characteristics}

Matched to Credit Report - Indicator for whether the 253,863 bankruptcy filings sent to TransUnion were matched to credit report data from the baseline filing year.

Missing Age - Indicator for whether age at filing is missing.

Missing Baseline Outcomes - Indicator for whether baseline credit report outcomes are missing.

\section{Housing Transitions}

Living in Same Residence - This measure is calculated based on the number of months at the current address calculated by TransUnion. We define a consumer as being in the same residence five years after filing if the difference between the number of months at the current address in year 5 and year 0 is at least 48 months.

Moved to Rental - We define this measure as individuals who have zero mortgage trades in year 5 , coupled with a move between years 0 and 5 (such that they are no longer in the same residence by year 5 ).

Moved to Home - We define this measure as individuals who have non-zero mortgage trades in year 5 , coupled with a move between years 0 and 5 (such that they are no longer in the same residence by year 5 ). 